\title{
Review \\ Uses of Nanoclays and Adsorbents for Dye Recovery: A Textile Industry Review
}

\author{
Daniel López-Rodríguez ${ }^{1}$, Bàrbara Micó-Vicent ${ }^{2, *}$, Jorge Jordán-Núñez ${ }^{2}$, Marilés Bonet-Aracil ${ }^{1}$ (D) \\ and Eva Bou-Belda ${ }^{1}$ \\ 1 Departamento de Ingeniería Textil y Papelera, Universitat Politècnica de València, Plaza Ferrándiz y \\ Carbonell s/n, CP 03801 Alcoy, Spain; dlopez@tecta.es (D.L.-R.); maboar@txp.upv.es (M.B.-A.); \\ evbobel@upvnet.upv.es (E.B.-B.) \\ 2 Departamento de Ingeniería Gráfica, Universitat Politècnica de València Plaza Ferrándiz y Carbonell s/n, \\ CP 03801 Alcoy, Spain; jorjornu@upv.es \\ * Correspondence: barmivi@upv.es
}

check for updates

Citation: López-Rodríguez, D.; Micó-Vicent, B.; Jordán-Núñez, J.; Bonet-Aracil, M.; Bou-Belda, E. Uses of Nanoclays and Adsorbents for Dye Recovery: A Textile Industry Review. Appl. Sci. 2021, 11, 11422. https:// doi.org/10.3390/app112311422

Academic Editor: Junseop Lee

Received: 9 October 2021

Accepted: 18 November 2021

Published: 2 December 2021

Publisher's Note: MDPI stays neutral with regard to jurisdictional claims in published maps and institutional affiliations.

Copyright: (c) 2021 by the authors. Licensee MDPI, Basel, Switzerland. This article is an open access article distributed under the terms and conditions of the Creative Commons Attribution (CC BY) license (https:// creativecommons.org/licenses/by/ $4.0 /)$.
Featured Application: Nanoclays can be used as adsorbent for waste water in several industries as textile. In addition the hybrid composites generated after the dye adsorption can be used as pigments in several applications as textile stamp, polymer composites (filature), $3 \mathrm{~d}$ printing, ceramic, cosmetic or even food industries depending on the hybrid components (natural dyes). Finally the desorption of the dyes is also possible with the nanoclays, allowing their reuse in other applications as textile dyeing, closing the manufacture circle without residues.

Abstract: Wastewater recovery is one of the most pressing contaminant-related subjects in the textile industry. Many cleaning and recovery techniques have been applied in recent decades, from physical separation to chemical separation. This work reviews textile wastewater recovery by focusing on natural or synthetic nanoclays in order to compare their capabilities. Presently, a wide variety of nanoclays are available that can adsorb substances dissolved in water. This review summarizes and describes nanoclay modifications for different structures (laminar, tubular, etc.) to compare adsorption performance under the best conditions. This adsorbent capacity can be used in contaminant industries to recover water that can be used and be recontaminated during a second use to close the production circle. It explores and proposes future perspectives for the nanoclay hybrid compounds generated after certain cleaning steps. This is a critical review of works that have studied adsorption or desorption procedures for different nanoclay structures. Finally, it makes a future application proposal by taking into account the summarized pros and cons of each nanoclay. This work addresses contaminant reuse, where part of the employed dyes can be reused in printing or even dyeing processes, depending on the fixing capacity of the dye in the nanoclay, which is herein discussed.

Keywords: nanoclay; dye recovery; clay pigment; montmorillonite; zeolite; bentonite; halloisite; saponite; sepiolite; hydrotalcite

\section{Introduction}

In recent decades, environmental alerts have been triggered by increasing concerns regarding caring for the environment. This has added to the possibility of optimizing and reducing the use of resources in industrial textile dyeing processes and has led the scientific community to look for options to recover or reuse the colorants in textile wastewater. The general objective of this research is to trap the colorant present in wastewater from dyeing processes by introducing a third element into the same bath. Some compounds or materials are known to be of use in this process, such as cyclodextrins [1], agricultural waste elements [2], and nanocomposites [3]; physical media, such as membrane filtration [4], among many other methods, can also be utilized. 
Industrial wastewater recycling has become an increasingly more evident need. The efforts of international governments to safeguard the environment have contributed to private companies taking action on the matter and making important investments in these fields [1,2,4-18]. The textile industry discharges organic and inorganic waste that produces bioaccumulation and can cause high degrees of toxicity [19] (Table 1, Figure 1).

Table 1. Fixation percentages of different families of colorants and their estimated loss in effluents [20].

\begin{tabular}{ccc}
\hline Family & Material & Fixation Degree (\%) \\
\hline Acids & Polyamide/Wool & $80-95$ \\
Azoics & Cellulosic & $75-90$ \\
Basics & Acrylic & $95-100$ \\
Direct & Cellulosic & $70-95$ \\
Scattered & Polyester & $90-100$ \\
Premetallized & Wool & $85-95$ \\
Reagents & Cellulosic & $60-90$ \\
Sulphurous & Cellulosic & $60-86$ \\
\hline
\end{tabular}

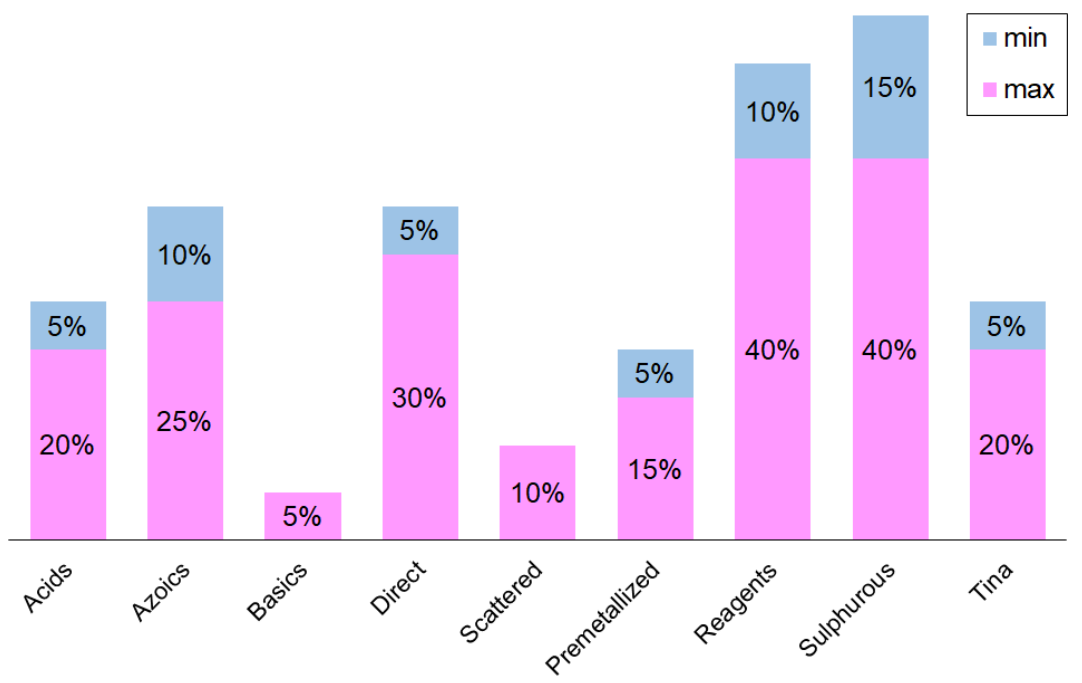

Figure 1. Loss in the effluent percentage.

The textile chemical industry is one that most affects wastewater, and it is the industry with the greatest chemical activity on earth [21]. Due to textile dyeing and stamping, colorants are one of the most common contaminants in the textile industry [22-24]. The concentration of colorants in effluents is around 50-1000 ppm, although 10-50 ppm can also be found [19]. The nature of their composition depends on the type of dye, considering fixation and estimated losses in the effluent, as shown in Table 1. Thus, it is very important to improve industries' ability to remove colorants from effluents. The development of low-cost absorbents by integrating advanced technology can significantly advance this area [25].

Other textile water treatment technologies performed by means of nanotechnology include the following: nanosorbents, including nanoclays, which this review is concerned with; nanosorbent- and carbon-based composites, which are mainly employed for water with $\mathrm{Ni}^{2+}$ [26,27]; and regenerable nanosorbent polymers, which are used instead of organic- and inorganic-type pollutants. Iron and carbon compounds are also capable of reducing large quantities of these different pollutants [26,28-30].

Other technologies can also be applied, such as carbon nanotubes, which remove heavy metals, dyes, and antibiotics [31-33]. Another possibility is to employ membranes that, depending on pore and molecule size, can remove pollutants such as oils, dyes, and germs by a simple procedure [31,34-37]. Another well-advanced technology is photocatalysts combined with other nanoparticles, which eliminate organic compounds, dyes, germs, and antibiotics by degradation [31,37-40]. 
The basic advantages of these technologies can be classified as follows: metal oxides, carbon nanotubes, and nanoclays are low-cost; nanotubes and membranes have highefficiency; and membranes and photocatalysts are easily applied [31].

The textile industry employs increasingly more synthetic dyes because they are easy to use, cheap, and offer good stability, and they come in a wide range of colors compared to natural dyes [41]. Artificial dyes are synthetic organic compounds that are molecularly dispersed and bind to textile substrates thanks to intermolecular forces. More than 10,000 dyes are available on today's market. Most are not easily biodegradable, given their complex aromatic molecular structure and synthetic origin [42]. As dye baths are not biodegradable in nature, and are toxic and inhibitory, they significantly and negatively affect both water and land. The fact that certain dyes or their metabolites are toxic or mutagenic and carcinogenic should also be taken into account [43]. Records worldwide [44,45] demonstrate the sensitive aspect of exposure to these synthetic substances at both high and low concentrations. Thus, they need to be removed before water is discharged.

For some years now, adsorption has become the most efficient technique to remove different dye types. The action of these absorbents is clearly affected by several parameters, such as dye concentration, the time the action lasts, temperature, dye particle size, and the concentration of the adsorbents, etc. Adsorption is clearly an efficient process in most physical, environmental, chemical, biological, and natural settings [46,47]. In industry, adsorption techniques are being applied by solids acting as adsorbents to purify wastewater and polluted water. In recent decades, different types of these adsorbents have been used to remove several types of pollutants from water [48].

This paper reviews the works that have focused on highly-efficient wastewater recovery. In line with their conclusions, it proposes reusing hybrid compounds in a circular economy concept. It shows the possibility of dye recovery using different adsorbents and presents a cheap and efficient procedure based on the advantages of nanoclays. In it, a future vision is proposed for the reuse of recovered dyes as new hybrid pigments protected by nanoclays, or via their desorption, to reuse them as dyes in other dyeing textile baths.

\section{Sewage Treatment}

Normal parameters exist for measuring contamination in general, which can be estimated with indicators such as biological oxygen demand at five days (BOD5) [49-51] and chemical oxygen demand (COD) [52-55], which indicate the amounts of oxygen needed to oxidize organic matter that is capable of being oxidized either biologically (bacteria and microorganisms) or chemically. There is one other parameter, the amount of total suspended solids (TSS) [56], which provides an idea of the amount of human matter in water.

\subsection{General Textile Recovery}

In order to reduce water use in the textile industry, wastewater can be totally or partially reused after its deep treatment. This treatment aims to leave a low contents of organic matter, color, suspended matter, and salinity in the water. This generally requires several purification processes, among which a biological process almost always takes place because, otherwise, BOD reduction is insufficient [57].

Other water recovery processes are known, such as reverse osmosis [58-60], microfiltration [61-63], ultrafiltration [64], and distillation in multiple-effect evaporators and electrochemical processes [65-67], which allow the economical and profitable recovery of various products. They can also be applied for recycling various process baths, but currently their cost is not economical enough for them to be fully used for waste effluents from the textile industry.

The objective of all these purification processes is to provide treated water that is of sufficient quality to be reused in industry. In fact, several industries are already supplied with recovered surface water that has undergone a natural dilution and purification process. 
In recent years, different techniques for treating textile effluents have been investigated [68]. Most of the published studies have focused on the elimination of colorants because this is the process that poses the greatest difficulty. Treating textile effluents by electrochemical techniques has been studied by several authors, with satisfactory results in color removal terms. However, this technique usually incurs high operational costs.

One of the emerging treatments for textile wastewater discoloration uses enzymatic methods [69]. Its main drawback is that the process variables must be well controlled (temperature, $\mathrm{pH}$, salinity, etc.). Furthermore, enzyme separation and purification are a very delicate process. Of the physico-chemical treatments, coagulation-flocculation is the most widespread because it is very effective in removing color. This technique, however, generates a concentrated residue that requires additional treatment. Adsorption discoloration (generally with activated carbon) is influenced by several parameters, such as interactions between the dye and adsorbent, the adsorbent's surface area, and particle size, etc. It is highly efficient for a wide variety of colorants, but is a high-cost technique because the adsorbent material must be regenerated after several treatments $[70,71]$. Ion exchange treatments also involve the resin regeneration problem but are not effective for all colorants. The best known physical treatments involve filtration techniques [72,73].

Chemical oxidation treatments require the addition of oxidizing compounds such as ozone $\left(\mathrm{O}_{3}\right)$, hydrogen peroxide $\left(\mathrm{H}_{2} \mathrm{O}_{2}\right)$, and permanganate $\left(\mathrm{MnO}_{4}{ }^{-}\right)$. Ozone is the most widely used for its high performance in eliminating colorants, but it is not effective when treating insoluble colorants such as fat or disperse dyes.

\subsection{With Nanotechnologies}

The use of nanotechnologies has attracted many researchers' attention for various industrial uses [74], including wastewater recovery with different residues, such as oil. Studies have been carried out using zeolites and nanoparticles that function mainly as catalysts and adsorbents, which have been used in refineries and petrochemical plants. Studies show that nanostructured zeolite can extract up to $40 \%$ more gasoline compared to other catalysts.

Some studies have been successful in designing highly selective nanocomposite membranes using a zeolite membrane. This membrane is effective in separating $\mathrm{O}_{2} / \mathrm{N}_{2}$ molecules in air. To date, no studies have yet been conducted on the direct application of zeolites to the enhanced oil recovery (EOR) process. However, the potential of the ion-exchange nature of zeolite given its porous structure may need to be investigated. This zeolite property could be useful for adsorbing cations, especially under high salinity conditions [16].

Nanoscale adsorbents generally have advantages over other conventional bulk elements thanks to their large specific surface area and high surface reactivities [20]. For example, modified nanoclays have been used as absorbents for non-ionic, anionic, and cationic dyes. From the differences in absorption between different chemical and morphological dye and clay structures, the adsorption forces that perform important functions have been identified.

Nanoclay can easily have an absorption capacity of more than $600 \mathrm{mg}$ of substrate per gram of sorbent and may also have $90 \%$ absorption at an initial dye concentration of $6 \mathrm{~g} / \mathrm{L}$, or of $60 \%$ based on the adsorbent's weight, which indicates an extremely high dye affinity. Studies show that, with certain modifications, nanoclay, e.g., montmorillonite, could easily become an excellent adsorbent for anionic, cationic, and non-ionic dyes [75].

\subsubsection{Nanoclays}

Nanoclay [76-109] is the general term used to refer to mineral clays with a phosilicate or laminar structure in the order of $\mathrm{nm}$ and surfaces of 50-150 nm or more. Despite nanoclay being commonly used, we must take into account that not all nanoclay dimensions are nanosized. Some clay dimensions classified as nanoclays are microsize due to agglomerations or their structure, such as motmorillonte laminar, which is nano in one 
laminar dimension but micro in the other. The mineral base can be synthetic or natural, and it is hydrophilic. The clay surface can be modified with specific compounds to improve its affinity and to make it compatible with, for example, polymers. The surface area of nanoclays is very large, around $750 \mathrm{~m}^{2} \cdot \mathrm{g}^{-1}$. When small amounts of these materials are incorporated into polymeric matrices, the result is known as a nanocomposite. Most of the dyes used in the textile industry are anionic, which is why achieving better adsorption performance can be expected from anionic nanoclays.

The nanoclays studied in this review present several advantages, such as their natural abundance, low cost, and high adsorption capacity. When such nanoclays act as inorganic hosts for organic compounds, they improve organic host properties to confer better fastness from chemical and natural environments. These nanoclays can be chemically synthesized to improve their physico-chemical characteristics. Another firm advantage of chemical synthesis is that there is no purification step, which is necessary with natural nanoclays to improve adsorption capacity.

Silicon and oxygen are common in all mineral clays. When combined with other elements, such as $\mathrm{Al}, \mathrm{Mg}, \mathrm{Fe}, \mathrm{Na}, \mathrm{Ca}$, and $\mathrm{K}$, and given the many ways in which these elements can be linked, they generate a large number of possible configurations. One important distinction in mineral clay properties is the ability of some to change volume by adsorbing water molecules from other polar ions in their structure. This is called the swelling property [110]. In the following, the most significant clays used for the recovery of wastewater in the textile industry will be described.

\subsubsection{Montmorillonite (MMT)}

Montmorillonite (MMT) (Figure 2) is the most abundant mineral in the smectites group. The chemical composition for montmorillonite is $80 \% \mathrm{SiO}_{2}, 13 \% \mathrm{Al}_{2} \mathrm{O}_{3}$, and $3 \%$ $\mathrm{Fe}_{2} \mathrm{O}_{3}$ [111]. It is a naturally abundant and cheap clay that offers efficient adsorbance. Its structure [112] is formed by two layers: a tetrahedric silicon one and an octahedric aluminium oxide one, which create a 2:1 diactahedral layer characterized by having a wide dehydroxylation temperature range of $500-700{ }^{\circ} \mathrm{C}$ [79,113-117]. MMT particle size can range between $2 \mu \mathrm{m}$ and $0.1 \mu \mathrm{m}$, with a mean of around $0.5 \mu \mathrm{m}$, although its particle size can be smaller when exfoliated in solvent. Particles are groups of not genuine crystal silicate laminate and their specific surface area (SSA) is approximately $31.26-57.19 \mathrm{~m}^{2} \cdot \mathrm{g}^{-1}$ [118]. MMT possesses permanent loads thanks to the isomorphic substitutions of silicate layers, but with no homogeneous distributions [119].

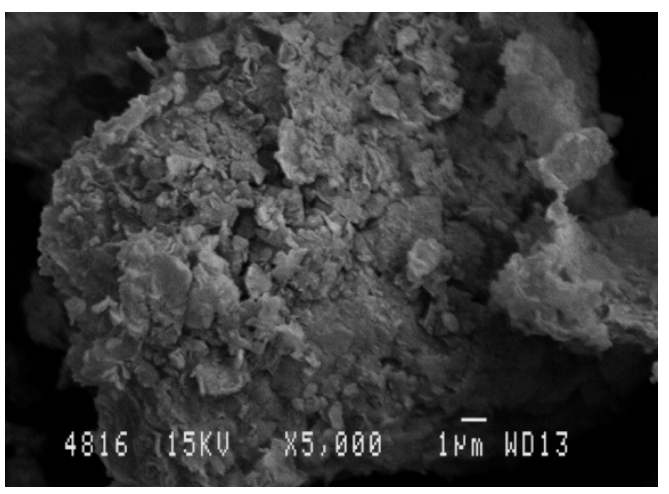

Figure 2. Montmorillonite (MMT) SEM.

The porosity and ion adsorption of MMT are both well-studied characteristics. The purpose of many research works has been to achieve wider basal spacing [120]. Thanks to MMT's cation exchange capacity (CEC), whose values are approximately $90-145 \mathrm{cmol} \cdot \mathrm{kg}^{-1}$ [121], scientists have improved MMT's adsorption and hydration capacities. Moreover, cation exchange alters clay porosity. All this makes MMT a potential element to be used as a purifier and filter. X-ray diffraction techniques have been applied to establish a direct 
relation between basal spacing and adsorption capacity, and its pore size [122]. Other studies have also verified that basal spacing is affected by both load type and the position of clays. Those with loads on tetrahedric layers have narrower basal spacing, while those with loads on octahedric layers possess wider basal spacing [123].

It is worth pointing out that isomorphic substitutions of trivalent aluminum for divalent magnesium or iron (II) leave clay crystals with a negative charge, which has to be compensated with surface cations. Clay's own nature determines its swelling and ion exchange capacities in adsorption phases. Much interest has been shown to this exchange control in recent decades [124]. With MMT, this control takes place by variation in $\mathrm{pH}$, and by the interlaminar space where ion exchange occurs.

In the nanoclay basal space, three different scenarios exist: when the basal space is minimum and the adsorption between the laminar nanoclay is minimum or null; when the basal space widens; and when nanoclay is totally exfoliated. This leads to a drawback: that of needing intermediate steps to improve MMT's adsorption capacity by taking into account large size-formed molecular dyes [112].

How $\mathrm{pH}$ affects the quantity of methylene blue dye, which clay can adsorb, has been studied. Indeed, MMT treated with acid interchanges leuko-derived dyes, and the stability of that obtained is greater when dye is placed between nanoclay layers. Some authors have concluded that treating clay with acid can allow more adsorbed dye [114-117,125]. In another work, Kang Peng and Huaming Yang prepared MMT by carbon hybridization to adsorb Congo Red dye [37]. MMT's hydrated carbon nanolayers were processed by saccharose calcining that, once formed, was able to adsorb $84 \%$ of the dye.

Studies have also been found that have demonstrated how the bath's ionic strength increases or decreases nanoclay adsorption capacity. Organic and inorganic salts influence the dispersion of nanoclay properties by conferring stable dispersion, coagulation, or even gel generation. As explained above, the basal space is significant for achieving the adsorption phenomenon [126-128].

\subsubsection{Zeolite}

Natural zeolite is a mineral widely used to treat wastewater. For the dehydrated zeolite, its chemical formula is $\left[\mathrm{Al}_{12} \mathrm{Si}_{12} \mathrm{O}_{48}\right]^{12-}$ [129]. Its different specific characteristics (e.g., porosity, surface area, permeability, CEC) give it a very particular behavior $[109,130,131]$. Its high specific surface areas is around 200-860 $\mathrm{m}^{2} \mathrm{~g}^{-1}$ [132]. Having processed natural zeolite, its particle size lies between $1 \mathrm{~mm}$ and $12 \mathrm{~mm}$. Its density is approximately double that of water, while its specific surface vastly varies and can be substantially increased by means of modifications [133]. For example, if the aim is to increase its surface, clay can be treated with nitric acid, which removes part of the aluminum from its structure to make it less crystalline and, hence, the specific surface increases [134] (Figure 3).

When analyzing its electric charge, both the total electric charge and the amount of cations in the zeolite skeleton remain quite stable in aqueous solution during the proton exchange process. Its CEC is around $563 \mathrm{cmol} \cdot \mathrm{kg}^{-1}$ [135]. However, zeolite possesses excellent absorption capacity because the number of exchanged ions during this process differs, and the electric field in the crystal changes [136]. Zeolite's characteristic channels and pores favor ion transport by promoting their transfer and capacity to adsorption $[109,137]$.

The main form by which zeolites are able to clean wastewater is by filtration and adsorption. When water pollutants pass through zeolite, they are captured, while water molecules pass through the pores [138]. Those pollutants trapped in zeolite in the previous phase are decomposed of microorganisms. After their decomposition, several plants adsorb them. In this way, the substratum is completely released from any previous impurity and can once again perform its function [139].

The zeolites used are either natural zeolites, which previous paragraphs have mentioned, or they are synthetic zeolites. When analyzing the size of component crystals, it is stressed that natural zeolites have a non-uniform crystal size because they contain other impurities, while synthetic zeolites are extremely pure, and their crystals are uniform in 
size. Zeolites also form differently because natural zeolites can take days or years to form, while they can be synthesized in a laboratory in just a few hours or days; their crystal size is extremely uniform, and their pore size can also be controlled by designing them according to given required specifications [140].
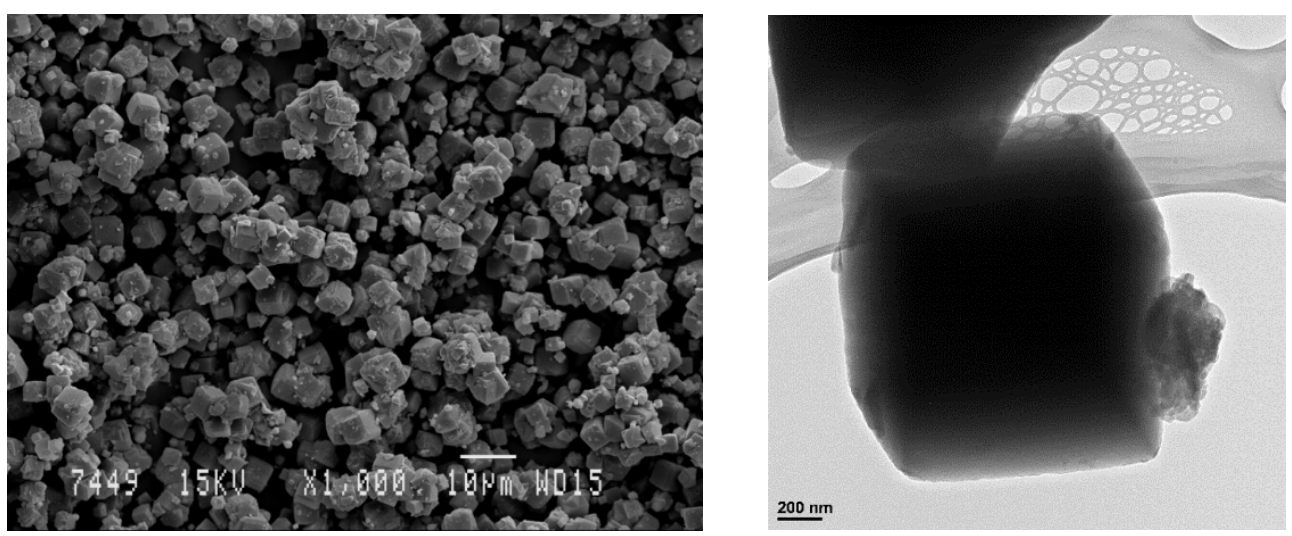

Figure 3. Zeiolite SEM (left) and TEM (right).

Synthetic zeolites can be obtained and used as artificial and natural elements. However, this does not imply that, from a cost perspective, any element is suitable for synthetization. The most widely used methods are hydrothermal [141], alkali-leaching [142], or sol-gel [143]. Each method is employed according to the desired zeolite type to be obtained. Evidently, it is necessary to bear in mind each method's limitations and advantages. In addition, certain limitations with these nanoclays should be considered, such as their nonreverse adsorption and secondary elements' steric blockage. Their porosity characteristics make high-molecule adsorption difficult [144].

The authors in [145] demonstrated that zeolite in basic or neutral medium is able to adsorb up to $99 \% \mathrm{Ni}$ (II), which is common in pigments. In [146], the authors bound zeolite to $\mathrm{TiO}_{2}$ to adsorb up to $99 \% \mathrm{Cd}$ (II) in any $\mathrm{pH}$ medium. Figure 4 shows the process of adsorption of dye by zeolite.

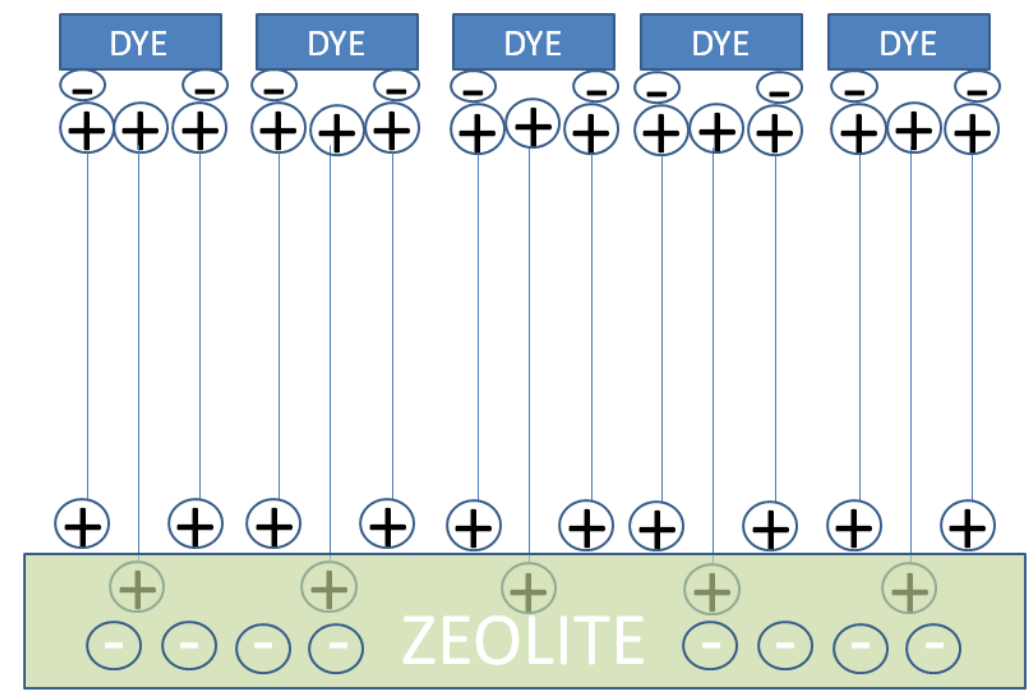

Figure 4. Zeolite adsorption of dye.

\subsubsection{Halloysite}

Today, scientists are working on employing adsorption by nanotechnologies because they consider it a very efficient method to remove different types of very harmful pollutants from water. Considerable importance has been attached to clayey minerals given 
their natural origin, the possibility of chemically synthesizing them, and their unique characteristics [147]. Halloysite is an example of a 1:1-type clayey that abounds in nature and is classified as a biocompatible material. The diameter of halloysite nanotubes (Figure 5) is approximately $40-70 \mathrm{~nm}$, and their length can be 200-2000 nm [148]. Their specific Surface Area (SSA), $47 \mathrm{~m}^{2} \cdot \mathrm{g}^{-1}$, and CEC, $9.45 \mathrm{cmol} \cdot \mathrm{kg}^{-1}$, have been determined by the authors [149] The interstratified phases are high-charge halloysite-smectite mixedlayered clays (CEC, 30-72 $\mathrm{cmol} \cdot \mathrm{kg}^{-1}$ clay) [150]. Their outer surface is negatively loaded and is composed of $\mathrm{SiO}_{2}$, while their inner area is positively loaded and composed of $\mathrm{Al}_{2} \mathrm{O}_{3}$ [151]. The use of halloysite nanotubes (HNT) has considerably increased thanks to them being cylindrical in nature and them having certain properties; e.g., their large area in relation to their size, drug release, low-cost, and thermal stability [148,152-154].
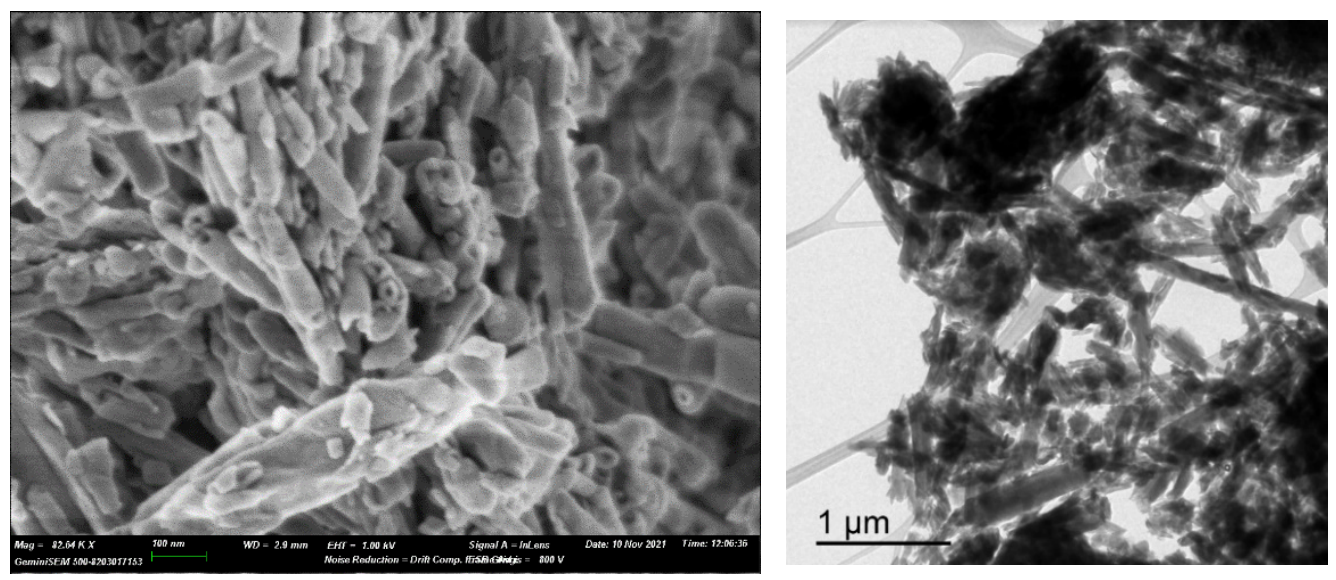

Figure 5. Halloysite SEM (left) and TEM (right) images.

In order to explain their aforementioned characteristics, HNT belong to the aluminosilicates family, where one octahedric aluminum oxide layer alternates with another tetrahedric silica layer. From this mismatch in the two described layer types, a characteristic hollow tubular form of this nanoclay is generated, which confers it specific characteristics that come about because of its nanoarchitecture [155]. It is important to consider that HNT properties derive mostly from their specific geological deposit, which is explained in the consulted literature [155-160]. Their biocompatibility makes them very useful for adsorbing dyes [161,162], such as methylene blue (MB) [163-171], azo dyes [172-178], triaryl and diaryl methane dyes [179-187], and xanthine dyes [161,188-190], and also for the biosorption of heavy metals [191]. One study has eliminated Orange G from simulated and real waters by combining halloysite with $\mathrm{ZnO}$ nanoparticles and by photocatalytic degradation. Up to $94 \%$ dye removal was achieved [192].

One of the most frequent problems in natural halloysite is its high concentration of impurities, which must be eliminated to improve adsorption capacity. Some authors describe how adsorption performance can be enhanced by using acid treatment for $12 \mathrm{~h}$ and by laminar surface injection [193].

\subsubsection{Saponite}

Saponite (Sap) is a trioctahedral clayey mineral that belongs to the 2:1-type smectites group, with silicate layers that intersperse with another gibbsite layer in the following form: silicate-gibbsite-silicate. It possesses negatively charged layers that are, in turn, neutralized by other ions with positive $\mathrm{Na}^{+} \mathrm{Mg}^{2+}$ charges. Saponite's cation exchange capacity (CEC) has been quantified as $100 \mathrm{cmol} \cdot \mathrm{kg}^{-1}$ [194-198]. XRD and SEM/EDX characterizations shows the clay mineral has the structural formula ${ }^{\mathrm{INT}} \mathrm{Na}^{\mathrm{TET}}\left[\mathrm{Si}_{7} \mathrm{Al}\right]^{\mathrm{OCT}}\left[\mathrm{Mg}_{6}\right] \mathrm{O}_{20}(\mathrm{OH})_{4}[199]$.

Its specific surface area (SSA) is large-sized and acidic. The specific surface area (SSA) was determined using ethylene glycol monomethyl ether, $100-115 \mathrm{~m}^{2} \cdot \mathrm{g}^{-1}$ [200]. Compared to other nanoclay minerals such as MMT, it can be stated that Sap offers greater 
thermal stability [201], a smaller particle size (approx. $50 \mathrm{~nm}$ ) [194-198], and is simpler to delaminate and exfoliate in nanoplate units, or as individual nanolayers in aqueous solution [202]. However, the downside of natural Spa is that it is not abundantly available. When Sap is exploited, a large quantity of impurities appear in the deposits, which entails time-consuming purification that considerably increases the cost of obtaining it [203]. The chemical composition of Sap varies significantly depending on the geological process that has formed it [204]. These defects can limit its use during adsorption processes [205].

The above-described problems have led researchers to opt to synthetically obtain Sap. This process consists of synthesizing similar solids to natural Sap with a controlled chemical composition. The most conventional method followed to synthesize Sap is normally hydrothermal synthesis [206-212]. This method can be modified to make this synthesis microwave-assisted [213,214].

Despite the characteristics described for both natural and synthetic Sap, Sap is not normally employed in its fundamental state without previously submitting it to modification, such as intercalation or hybridization. Researchers have put saponite swelling to best use [215-218] to introduce functional groups into the structure. This enables the modification of acidity and porosity, and different physico-chemical properties. Distinct hybrids have been successfully achieved by following these guidelines [219-222]. An increasing number of studies have demonstrated that Sap can be employed as an efficient adsorbent $[222,223]$. In the work by Herney-Ramirez et al., dye Acid Orange 7 was degraded by Sap by employing $\mathrm{H}_{2} \mathrm{O}_{2}$ at $70{ }^{\circ} \mathrm{C}$ as a catalyst, which achieved over $90 \%$ degradation when clay was impregnated with $\mathrm{Fe}$ (II) [224].

\subsubsection{Sepiolite}

Sepiolite is a natural 2:1-type fibrous nanoclay mineral [225] whose molecular formula is $\mathrm{Si}_{12} \mathrm{O}_{30} \mathrm{Mg}_{8}(\mathrm{OH})_{4}\left(\mathrm{H}_{2} \mathrm{O}\right)_{4} \cdot 8 \mathrm{H}_{2} \mathrm{O}$. Type $2: 1$ is defined by two tetrahydric silica layers, which are interspersed with another octahedric magnesium oxide layer. Its shape is similar to that of zeolites because it is formed by ribbon-like composites that, in turn, form an open channel. Thanks to such a structure (approx. $0.4 \mathrm{~nm} \times 1 \mathrm{~nm}$ ), it can be generated by the penetration of organic and inorganic cations. The sepiolite surface has many silanol ( $\mathrm{Si}-\mathrm{OH})$ groups as a result of a discontinued silica sheet on the outer 2:1 layers [226-229] (Figures 6 and 7).
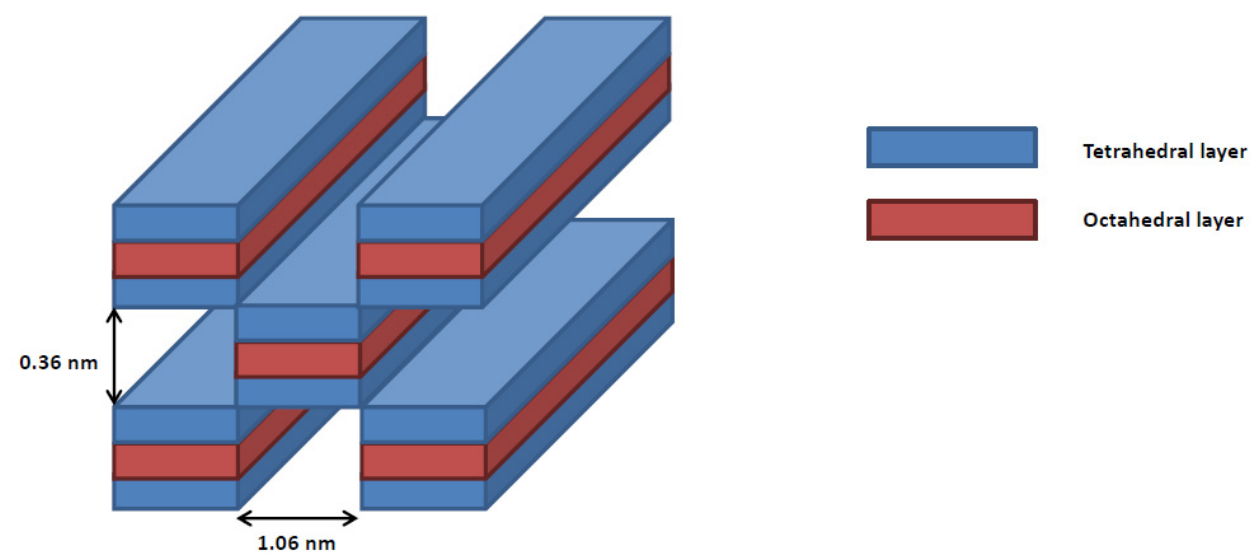

Figure 6. Sepiolite Type 2:1 two tetrahydric silica layers, and another octahedric.

On the sepiolite structure, three modification/adsortion zones are distinguished: $\mathrm{Si}-\mathrm{OH}$ groups along the component fiber axis; oxygen ions on the tetrahedric silica layers; and a few cationic exchange gaps. Other parameters that affect sepiolite's adsorption capacity are the load of the substance to be adsorbed and its shape and size. By bearing these parameters in mind, some researchers have found that substances presenting lowpolarity and large molecular-sized molecules cannot enter sepiolite channels and, despite being adsorbed on the tetrahedric silica layer, they only represent about $40 \%$ total SSA [230]. 
Unlike MMT, it is possible to introduce an organic modifier into the sepiolite surface (between $400 \mathrm{~m}^{2} \cdot \mathrm{g}^{-1}$ and $500 \mathrm{~m}^{2} \cdot \mathrm{g}^{-1}$ ) [231].

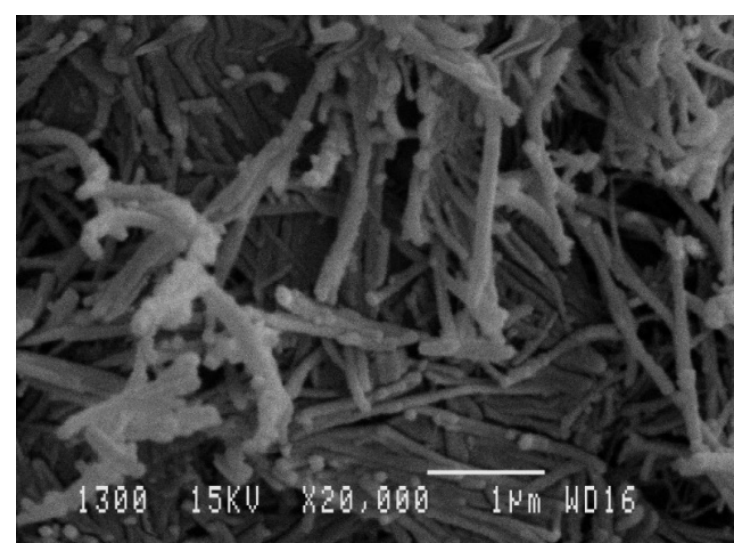

Figure 7. Sepiolite SEM.

Sepiolite is frequently industrially and scientifically commercialized as an excellent absorbent in pet latrines, and its efficiency as an adsorbent for textile industry dyes has also been demonstrated. Some studies have experimentally shown sepiolite's capacity for adsorbing different cationic dyes [232-235]. It adsorbs cationic substances thanks to this clay's CEC ( $\left.31.4 \mathrm{cmol} \cdot \mathrm{kg}^{-1}\right)$ [236], which also occurs through neutral gaps that favor the adsorption of cationic dyes [233]. Saturation with Na or Ca increases sepiolite's adsorption capacity for methylene blue dye [237]. However, it does not offer good adsorption results with azo acid dyes [238]. One study employed $\mathrm{SiO}_{2}-\mathrm{Mg}(\mathrm{OH})_{2}$ derived from sepiolite to remove the $\mathrm{Cd}$ (II) present in dye with up to $95 \%$ adsorption [239]. It worked considerably better at a neutral $\mathrm{pH}$ than at a basic $\mathrm{pH}$, and at constant temperature $\left(\mathrm{T}=25^{\circ} \mathrm{C}\right)$ [240].

The $\mathrm{pH}$ parameter is important because it affects sepiolite's adsorption capacity. Due to isomorphous nanoclay substitutions, their structural charge can be changed by $\mathrm{pH}$, which leads to hidroxyl dissociation [240].

\subsubsection{Bentonite}

Bentonite (BTE) is an aluminosilicate formed by one octahedric aluminum oxide layer and two tetrahedric silicon oxide layers, which results in a 1:2-type structure with the chemical formula $\mathrm{Al}_{2} \mathrm{H}_{2} \mathrm{Na}_{2} \mathrm{O}_{13} \mathrm{Si}_{4}$ [241,242]. This clay is frequently employed worldwide as an adsorbent because of its excellent cost-effectiveness ratio. It is also widely available anywhere in the world. Some authors explain bentonite's high adsorption capacity with the $\mathrm{NH}_{4}{ }^{+}$group, which is formed thanks to its high CEC, with a value generally around $40-130 \mathrm{cmol} \cdot \mathrm{kg}^{-1}$. Some studies conducted in 2017 by scientists revealed that raw bentonite has a $\mathrm{NH}^{4+}$ adsorption capacity of $19.01 \mathrm{mg} \cdot \mathrm{g}^{-1}$, which implies $53 \%$ adsorption efficacy, which can rise to $81 \%$ when the quantity of nanoclay is increased up to a concentration of $40 \mathrm{~g} \cdot \mathrm{L}^{-1}$ [243-247].

As with many other nanoclays, modifications can be made to bentonite to change its properties. After analyzing the SSA $\left(45-68 \mathrm{~m}^{2} \cdot \mathrm{g}^{-1}\right)$ [248], diameter, and pore volume of BTE modified with benzylhexadecyldimethylammonium chloride and a natural unmodified bentonite, Tohdee and Kaewsichan concluded that, without modifications, the values of these parameters were more specific and better than those recorded after modification [249]. Moreover, cationic surfactants increased the cationic affinity of clay and their anionic adsorption. The modification made by the action of these elements only occurred on surface layers [250].

An example of these cationic surfactants appears in another study, which modified bentonite with cetrimonium bromide to give pores and a larger surface area after modifications. This led to greater adsorption capacity and, therefore, to amaranth dye removal [251]. Different parameters, such as $\mathrm{pH}$ [252-255], quantity of adsorbent [256,257], temperature, and contact time [258-260] among other elements, influenced bentonite's adsorption capacity. 
One study employed Zr-bentonite to remove the phosphates that abounded in textile water to adsorb them under acidic $\mathrm{pH}$ conditions. Removal efficiency came close to $100 \%$, but removal efficiency lowered as $\mathrm{pH}$ rose. Another important factor was the quantity of $\mathrm{NaCl}$ in the medium because removal efficiency increased at lower $\mathrm{NaCl}$ concentrations. The final phosphate removal capacity in that study was 95\% $[261,262]$.

\subsubsection{Laponite}

Laponite (Lap) is an inorganic stratified silicate element that is often used to improve the rheology of different water-based products [263-265]. Its capacity to react with water-based components is excellent, and its viscosity develops when such products are incorporated [266]. Some studies [267-269] have demonstrated that Lap can be dispersed in water (Figure 8) and can improve other elements' dispersion in solution thanks to its ability to prevent solid aggregation [97,270-273].

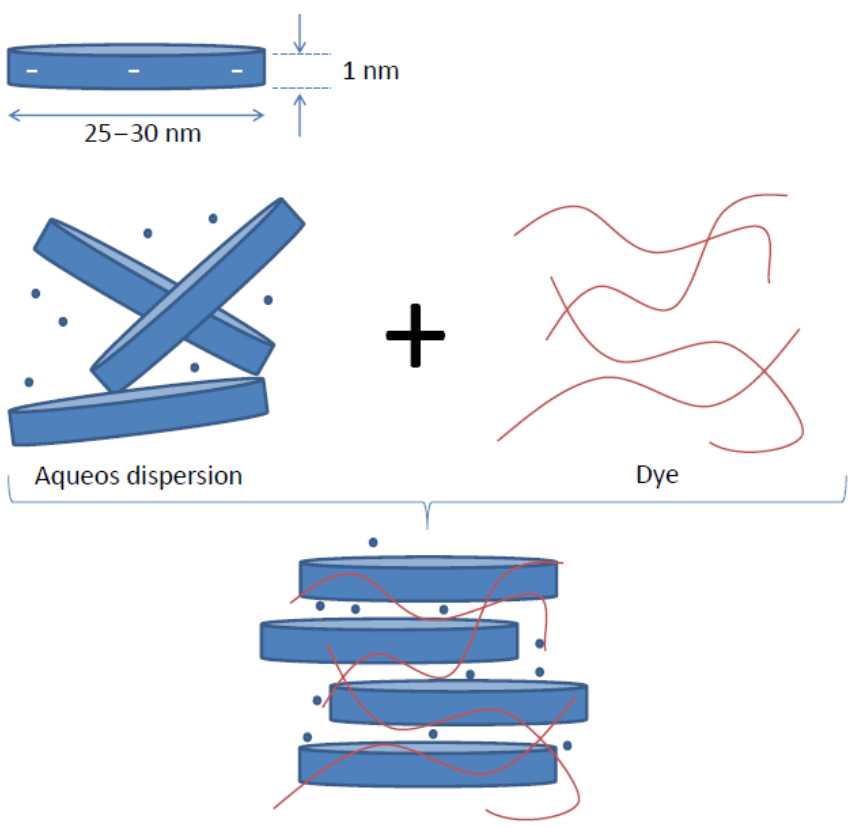

Figure 8. Laponite aqueous dispersion and dye adsorption.

Synthetic Lap $\left(\mathrm{Si}_{8}\left[\mathrm{Mg}_{5.5} \mathrm{Li}_{0.4} \mathrm{H}_{4.0} \mathrm{O}_{24}\right]^{0.7-} \mathrm{Na}_{0.7}{ }^{+}\right)$is a $2 \mathrm{D}$ clay disc-shaped silicate that is approximately $1 \mathrm{~nm}$ thick. Its diameter is $25 \mathrm{~nm}$ [274-276]. The raw Laponite was estimated to have an SSA of $11.7 \mathrm{~m}^{2} \cdot \mathrm{g}^{-1}$ [277]. It possesses permanent negative charges due to isomorphic substitution. Depending on the temperature, the concentration it is found at, and the curing time, it can come as a viscous gel that breaks in aqueous solution or forms a translucent fluid [278-281]. In the textile industry, it can act as a perfect additive for pigments because it protects them from environmental factors, such as temperature and oxygen, and improves the pigment's final stability [282-285].

Some studies have demonstrated the adsorption capacity of laponite-based hydrogels [286] and their CEC is $74 \mathrm{cmol} \cdot \mathrm{kg}^{-1}$ [287]. Laponite-based hydrogel formation is due to the reticulation that occurs in the polymer. This gel can also be formed if certain components are added to it, such as $\mathrm{H}_{2} \mathrm{SO}_{4}$ or $\mathrm{KNO}_{3}$ [274-288]. By means of Lap membranes, another study accomplished the removal of up to $100 \%$ of two organic dyes, namely Rhodamine B (cationic dye) and Brilliant Blue (anionic dye) [288]. To do so, a superoleophobic membrane was synthesized from hydrating polyacrylonitrile.

\subsubsection{Hydrotalcite}

Hydrotalcite, $\mathrm{Mg}_{6} \mathrm{Al}_{2}\left(\mathrm{CO}_{3}\right)(\mathrm{OH})_{16} \cdot 4\left(\mathrm{H}_{2} \mathrm{O}\right)$ (Figure 9), is classified as a nano-sized mineral because one of the dimensions of its laminate measures less than $20 \mathrm{~nm}$. Owing to 
its characteristic structure, it falls into the "layered double hydroxides" (LDH) category. This layer has an SSA between $71 \mathrm{~m}^{2} \cdot \mathrm{g}^{-1}$ and $104 \mathrm{~m}^{2} \cdot \mathrm{g}^{-1}$ [289]. Researchers are showing increasing interest in such elements thanks to their wide range of applications as catalysts, and also in medicine, adsorption, etc. [290]. Different methods exist by means of which the adsorption of anions by LDH composites takes place. The most common one is that produced by direct adsorption in dispersion. A solid's crystallinity limits such adsorption for the following reasons: the medium's polarity, temperature, anion size, and $\mathrm{pH}$ [291-293].

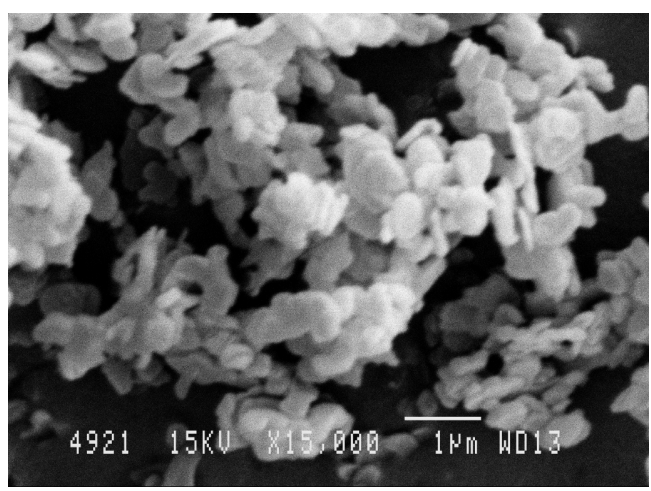

Figure 9. Hydrotalcite SEM.

The second, albeit slightly more time-consuming, method, but one offering clear advantages, is calcining. Former studies have demonstrated that hydrotalcite has shape memory after being exposed to a high thermal source. This substantially changes its initial laminar arrangement, which recovers during later hydration processes. After being exposed to temperatures of $450-550{ }^{\circ} \mathrm{C}$, it is reconstructed as previously described thanks to the anions present in dissolution and their incorporation into the new nanoclay structure [294-296] (Figure 10).

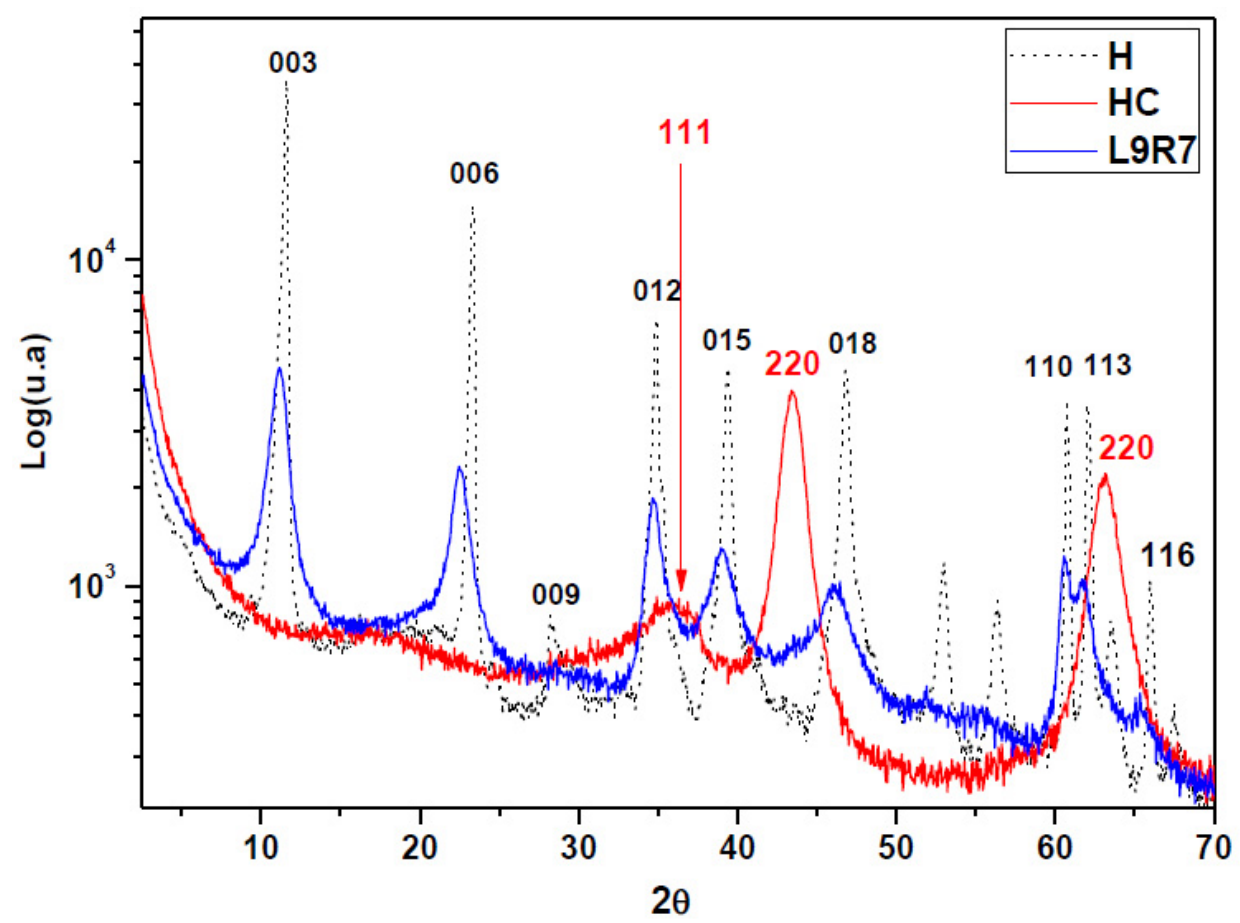

Figure 10. XRD from Hydrotalcite after heat treatment, $600{ }^{\circ} \mathrm{C}, 3 \mathrm{~h}(\mathrm{HC})$ : original hydrotalcite (HC) and hydrotalcite reconstructed after a natural dye (from beetroot) adsorption in different bath conditions (L9R7). 


\section{Reused Waste Water Dyes}

The third form of adsorption is coprecipitation, based on the synthesization of hydrotalcite with some anions, which are incorporated into its structure and are adsorbed [297]. Dye adsorption by cationic exchange cannot be performed in most dyes found in nature because they are anionic, which is why hydrotalcite-type clays are resorted to for this recovery [298]. Hydrotalcite's laminar structure needs to be compensated by anions being incorporated into it, which results in the aforementioned adsorption [209,299].

Hence, high adsorbance can be accomplished, but other processes are necessary to improve this capacity to achieve the desired properties during the adsorption process. It is important to consider the CEC for this nanoclay, calculated by the authors Gasser, Mekhamer, and Abdel, Rahman in this work [300], which has a value of $8.96 \mathrm{cmol} \cdot \mathrm{kg}^{-1}$.

After carrying out the different dyeing processes, wastewater is discharged without having to wait for further use. However, in view of the studies included in this article, it is possible to recover a large portion of the dyes in solution to be reused during industrial processes.

\subsection{Pigment}

One of the options that has been applied to the reuse these colorants is to employ them as pigments $[76,229,262,301-304]$. Once trapped inside a substrate such as clays, they can remain in this element to be later utilized during stamping processes.

In order to be used as pigments, their stability must be good, and it is necessary to ensure that the colorant does not undergo any desorption processes. Therefore, after introducing the colorant into clay, tests are carried out, during which the colorant's degree of fixation is analyzed. Only in the event of having high fixation results can its use as a pigment with no discoloration risk due to loss of colorant be guaranteed.

These pigments are very frequently used in industries, such as textiles, plastics, printing, or industrial coatings, although they have a series of properties that confer them with low stability, poor weather resistance, and poor dispersion, which mean their use is limited $[305,306]$. Thus, in order to improve the described properties and defects, it is necessary to prepare stabler hybrids with colorants in clay mineral matrices [307]. By way of example, some works exist where hybrids with montmorillonite and methylene blue have been prepared, where thermal stability, photostability, and covering power have improved [308,309].

Other works have compared the color and stability properties of dye-clay hybrids. These studies, based on a CIELAB 1976 analysis [310], conclude that the color stability of the hybrids formed by halloysite were superior to others, such as MMT and sepiolite [311], which can be attributed to each nanoclay's individual structure and chemical properties.

\subsection{Dyes}

Another reuse option involves employing recovered colorant during another dyeing process. In this case, the clay-dye bond must be less to allow desorption, unlike the previous situation of utilizing a pigment. For this purpose, clays such as Lap are used $[97,312]$ that, according to tests, presents some degrees of desorption from $20 \%$ to $40 \%$. Another example of a mineral that allows dye desorption is zeolite [109].

According to the bibliography, desorption processes are carried out by subjecting clay to a bath with either distilled water [312] or ethanol [229], and by means of stirring. This results in dye desorption.

A study carried out by Momina, Shahadat Mohammad, and SuzylawatiIsamil [313] (Figure 11) explains how to proceed with MB desorption by subjecting the clay-dye hybrid to temperature and then using various solvents such as $\mathrm{HCl}$, ethanol, nitric acid, or acetone. Their study revealed that it was not enough to apply thermal energy to break the bonds that formed during dye adsorption by clay, which they called a chemisorption process. The solvent and heating processes alone did not provide enough energy, which is why they had to apply a thermo-chemical process to regenerate the adsorbent. 

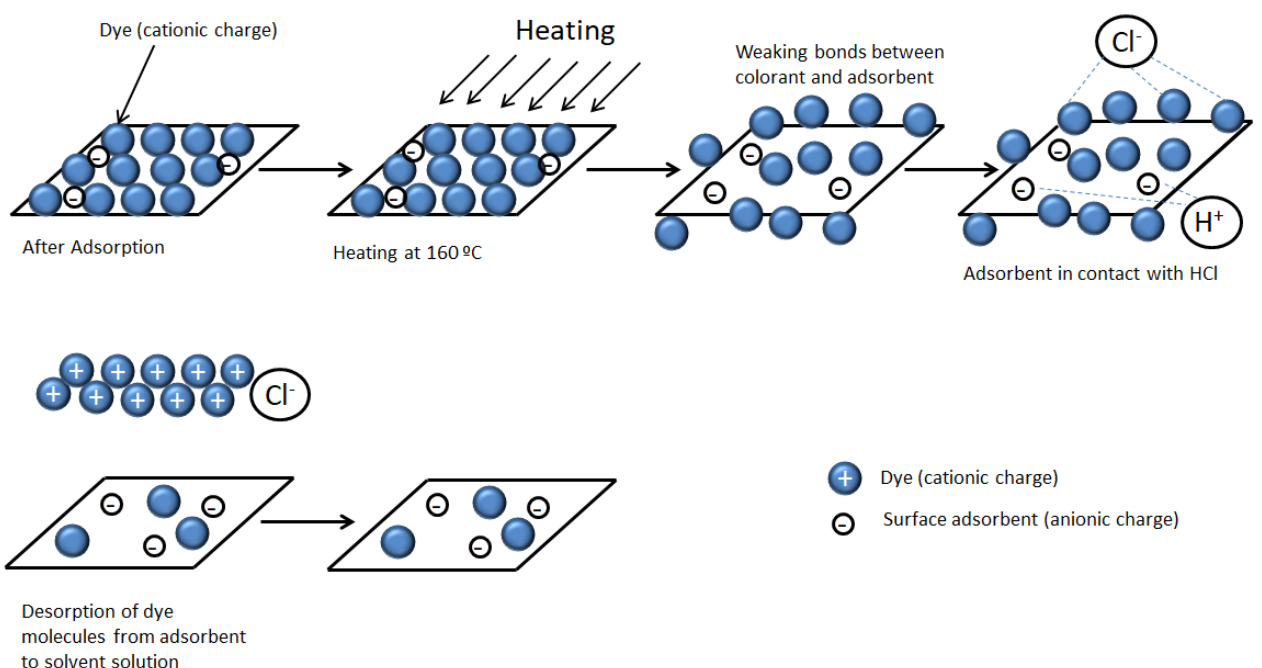

Figure 11. Dye desorption process.

The process begins by heating samples to about $150-200{ }^{\circ} \mathrm{C}$ for $45 \mathrm{~min}$. Accordingly, the bonds between the adsorbent and the colorant weaken. In the next step, $\mathrm{HCl}^{-}$is introduced, which increases the charges of the positive hydrogens, which show an affinity for the clay surface and release $\mathrm{Cl}^{-}$charges with an affinity for MB. In this way, desorption is completed by releasing the colorant from the clay. As both elements are ionically neutralized, they do not rejoin.

As a critical aspect of this procedure, the maximum temperature that both the clay and the dye can withstand should be studied by thermogravimetric (TGA) to increase the temperature of the initial phase to a maximum and to thus weaken the bonds as much as possible and facilitate the second phase by maximizing desorption efficiency.

\section{Conclusions}

This article describes some of the most widespread nanoclays, referring to different sources of adsorbents research, that can be used for treating industrial wastewater (Table 2). Each clay material has specific characteristics (Table 3), which can make them more appropriate in different situations according to their subsequent utilization, cost optimization, or other factors.

Table 2. Comparison of different clays.

\begin{tabular}{|c|c|c|c|c|c|}
\hline Adsorbent & Performance & Use & Observ. & Adsorption BC * & Biblio. Ref. \\
\hline Saponite & High performance & Pigment & - & Acid Orange $7>90 \%$ & {$[76,82,224,301]$} \\
\hline Montmorillonite & Thermal stability & Pigment & No desorption & Congo Red 84\% & {$[37,301,302,314]$} \\
\hline Sepiolite & Poor stability & Pigment/Dye & Desorption in ethanol & Cd $95 \%$ & {$[229,239]$} \\
\hline Bentonite & $\begin{array}{l}\text { No desorption High } \\
\text { stability }\end{array}$ & Pigment & $\begin{array}{l}\text { Low-cost. Absorbance } \\
\text { at different } \mathrm{pH} \text {. }\end{array}$ & Phosphates 95\% & {$[261,262,303,304]$} \\
\hline Laponite & 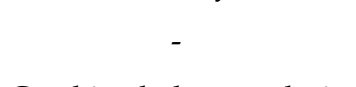 & Dye & $20-40 \%$ desorption & $\begin{array}{l}\text { Rhodamine B\% } \\
\text { 100\% Brilliant blue }\end{array}$ & {$[97,288,312]$} \\
\hline Halloysite & Combined photocatalysis & Pigment & Novelty & $90 \%$ orange $\mathrm{G}$ & {$[89,192]$} \\
\hline Zeolite & Regeneration for reuse & Dye & With cationic dyes & $99 \% \mathrm{Ni} \& \mathrm{Cd}$ & {$[109,145,146]$} \\
\hline Hydrotalcite & High performance & Pigment & Low-cost & Cationic dyes & {$[209,299]$} \\
\hline
\end{tabular}

* BC: Under Best Conditions.

From this state-of-the-art review, we found a strong nanoclay repercussion on wastewater treatment, specifically in textile wastewater with a high dye concentration. Despite the huge amount of clays and nanoclays that can be employed as adsorbents, we focused on the most widely studied nanoclays. The most well-studied ones were selected for their abundance, low-cost, and excellent adsorption efficiency. The main studied nanoclays 
can be found under natural conditions, and they can also be synthesized to improve their characteristics. Despite most authors supporting nanoclays for their low cost and abundance, we found that information regarding this, supported with specific numbers and comparisons to real costs, exploitation capabilities, and the real impact of exploitation or synthetic generation, was lacking. In addition, a synthetic or natural extraction comparison should be made, taking into account the purification step costs of natural clays.

Table 3. Adsorbents' characteristics comparison.

\begin{tabular}{cccc}
\hline Adsorbent & Structure & Charge & Biblio. Ref. \\
\hline Saponite & Laminate & Cationic & {$[194]$} \\
Montmorillonite & Laminate & Cationic & {$[79]$} \\
Sepiolite & Channels & Cationic & {$[226-229]$} \\
Bentonite & Laminate & Cationic & {$[241]$} \\
Laponite & Laminate & Cationic & {$[97,275,276]$} \\
Halloysite & Tubular & Cationic/Anionic & {$[155]$} \\
Zeolite & Channels & Cationic & {$[109,137]$} \\
Hydrotalcite & Laminate & Cationic & {$[209,299]$} \\
\hline
\end{tabular}

Hundreds of studies have demonstrated that nanoclays are highly efficient adsorbents, and several dye structures are used during industrial processes, such as textile dyeing. The ionic exchange process that they bring about means that dye molecules are trapped in the nanoclay basal space or adhere to nanoclay surfaces. For these reasons, it is adsorption and not an absorption process that improves some of their characteristics, such as colorfastness in the event of environmental and chemical attacks, and they can be used later in textile stamping.

Nanoclay modification to improve their adsorption capacity via calcination or with surface modifiers has been widely studied. However, some authors have not considered the environmental costs of this process. The acid, basic, or thermal treatment costs should also be considered in order to ensure that the process is clean and sustainable. On the other hand, when different authors discuss the desorption phase, they tend to give very ambiguous results; for example, they give desorption values of between $20-40 \%$, which is not very specific because the range of variation is very wide. For future lines of enquiry, the quantification of many of the phases must be improved, for example, the preparation of materials where their adsorption capacity is improved by prior calcination, because it is not quantified to what degree the adsorption capacity improves due to previous loss of anions $\mathrm{CO}_{3}$.

Regarding post-dye adsorption hybrid pigment uses, we found several works that demonstrated their advantages, such as improving organic dye properties, or polymer thermal, mechanical, and thermal barrier properties, in nanocomposites. However, a textile application has not yet been studied in-depth, nor has the reuse of organic compounds after a desorption process been completely studied and described. Several factors must be considered and described, such as $\mathrm{pH}$, time, and temperature, which recent works do not provide. The results obtained by these studies are ambiguous and need to be further examined. However, these studies do demonstrate that the desorption process is viable as a promising future trend.

The possibilities contained within this study and proposal are many, such as the impact on textile fibers or the desorption possibility to separately reuse dyes as raw material during dyeing processes and the use of nanoclay as an adsorbent during the wastewater cleaning process. Future applications should be considered according to the nanoclay properties described, such as cation exchange capacity (CEC) and specific surface area (SSA), etc. Each one presents specific characteristics that allow it to retain the colorant to a greater or lesser extent. Those that retain the colorant and do not present desorption will be suitable for later use in the printing industry, while those with an acceptable degree of desorption will allow a new dye bath to be made and, therefore, the residual colorant left in water can be reused. 
Funding: This research received no external funding.

Institutional Review Board Statement: Not applicable.

Informed Consent Statement: Not applicable.

Data Availability Statement: Not applicable.

Conflicts of Interest: The authors declare no conflict of interest.

\section{References}

1. Semeraro, P.; Rizzi, V.; Fini, P.; Matera, S.; Cosma, P.; Franco, E.; García, R.; Ferrándiz, M.; Núñez, E.; Gabaldón, J.A.; et al. Interaction between Industrial Textile Dyes and Cyclodextrins. Dye. Pigment. 2015, 119, 84-94. [CrossRef]

2. Sana, D.; Jalila, S. A Comparative Study of Adsorption and Regeneration with Different Agricultural Wastes as Adsorbents for the Removal of Methylene Blue from Aqueous Solution. Chin. J. Chem. Eng. 2017, 25, 1282-1287. [CrossRef]

3. Sanchez, L.M.; Ollier, R.P.; Gonzalez, J.S.; Alvarez, V.A. Nanocomposite Materials for Dyes Removal. In Handbook of Nanomaterials for Industrial Applications; Elsevier: Amsterdam, The Netherlands, 2018; pp. 922-951. [CrossRef]

4. $\quad$ Erkanlı, M.; Yilmaz, L.; Çulfaz-Emecen, P.Z.; Yetis, U. Brackish Water Recovery from Reactive Dyeing Wastewater via Ultrafiltration. J. Clean. Prod. 2017, 165, 1204-1214. [CrossRef]

5. Ranjan, P.; Verma, P.; Agrawal, S.; Rao, T.R.; Samanta, S.K.; Thakur, A.D. Inducing Dye-Selectivity in Graphene Oxide for Cationic Dye Separation Applications. Mater. Chem. Phys. 2019, 226, 350-355. [CrossRef]

6. Mahmoud, M.E.; Nabil, G.M.; Khalifa, M.A.; El-Mallah, N.M.; Hassouba, H.M. Effective Removal of Crystal Violet and Methylene Blue Dyes from Water by Surface Functionalized Zirconium Silicate Nanocomposite. J. Environ. Chem. Eng. 2019, 7, 103009. [CrossRef]

7. Azzaz, A.A.; Assadi, A.A.; Jellali, S.; Bouzaza, A.; Wolbert, D.; Rtimi, S.; Bousselmi, L. Discoloration of Simulated Textile Effluent in Continuous Photoreactor Using Immobilized Titanium Dioxide: Effect of Zinc and Sodium Chloride. J. Photochem. Photobiol. A Chem. 2018, 358, 111-120. [CrossRef]

8. Azzaz, A.A.; Jellali, S.; Akrout, H.; Assadi, A.A.; Bousselmi, L. Dynamic Investigations on Cationic Dye Desorption from Chemically Modified Lignocellulosic Material Using a Low-Cost Eluent: Dye Recovery and Anodic Oxidation Efficiencies of the Desorbed Solutions. J. Clean. Prod. 2018, 201, 28-38. [CrossRef]

9. Rizvi, M.A.; Moosvi, S.K.; Jan, T.; Bashir, S.; Kumar, P.; Roos, W.D.; Swart, H.C. Dielectric, Magnetic and Photocatalytic Activity of PolyPyrrole/Prussian Red Nanocomposite for Waste Water Treatment Applications. Polymer 2019, 163, 1-12. [CrossRef]

10. Park, J.-H.; Wang, J.J.; Meng, Y.; Wei, Z.; DeLaune, R.D.; Seo, D.-C. Adsorption/Desorption Behavior of Cationic and Anionic Dyes by Biochars Prepared at Normal and High Pyrolysis Temperatures. Colloids Surfaces A Physicochem. Eng. Asp. 2019, 572, 274-282. [CrossRef]

11. Jadhav, S.A.; Garud, H.B.; Patil, A.H.; Patil, G.D.; Patil, C.R.; Dongale, T.D.; Patil, P.S. Recent Advancements in Silica Nanoparticles Based Technologies for Removal of Dyes from Water. Colloid Interface Sci. Commun. 2019, 30, 100181. [CrossRef]

12. Wang, L.; Zhang, W.; Wang, L.; Wu, H.; Wu, D.; Lu, S.; Huang, X. Synthesis Rod-like Mesoporous MgO Using Sodium Polystyrenesulfonate (PSS) as Structure-Direct Template and Its Application to Plumbum Absorption in Waste Water. Mater. Lett. 2020, 285, 129051. [CrossRef]

13. Nong, G.Z.; Xing, D.Y.; Li, Y.J.; Zhu, T.; Wu, J.L.; Gan, W.X.; Wang, S.F.; Li, X.R. Recycle Cooking Wood Chips with the Residue Liquid Removed out of Lignin by Calcification for Increasing Pulp Yield and Reducing Waste Water Discharge. J. Clean. Prod. 2020, 277, 124028. [CrossRef]

14. Mahmoud, M.E.; Nabil, G.M.; Khalifa, M.A.; El-Mallah, N.M.; Hassouba, H.M.; Negin, C.; Ali, S.; Xie, Q.; Liu, H.; Li, X.R.; et al. A Review on Biocatalytic Decomposition of Azo Dyes and Electrons Recovery. J. Clean. Prod. 2017, 246, 275-281. [CrossRef]

15. Liu, H.; Li, X.; Li, M.; Zhang, Y.; Tang, K.; Liu, J.; Zheng, X.; Pei, Y. A Simple and Sustainable Beamhouse by the Recycling of Waste-Water from KCl-Dispase Synergistic Unhairing in Leather Making. J. Clean. Prod. 2020, 124535. [CrossRef]

16. Negin, C.; Ali, S.; Xie, Q. Application of Nanotechnology for Enhancing Oil Recovery-A Review. Petroleum 2016, 2, 324-333. [CrossRef]

17. Zhong, P.S.; Widjojo, N.; Chung, T.-S.; Weber, M.; Maletzko, C. Positively Charged Nanofiltration (NF) Membranes via UV Grafting on Sulfonated Polyphenylenesulfone (SPPSU) for Effective Removal of Textile Dyes from Wastewater. J. Membr. Sci. 2012, 417-418, 52-60. [CrossRef]

18. Senoussi, H.; Bouhidel, K.-E. Feasibility and Optimisation of a Batch Mode Capacitive Deionization (BM CDI) Process for Textile Cationic Dyes (TCD) Removal and Recovery from Industrial Wastewaters. J. Clean. Prod. 2018, 205, 721-727. [CrossRef]

19. Mathew, M.L.; Gopalakrishnan, A.; Aravindakumar, C.T.; Aravind, U.K. Low-Cost Multilayered Green Fiber for the Treatment of Textile Industry Waste Water. J. Hazard. Mater. 2019, 365, 297-305. [CrossRef]

20. Zhang, W.; Zhang, D.; Liang, Y. Nanotechnology in Remediation of Water Contaminated by Poly- and Perfluoroalkyl Substances: A Review. Environ. Pollut. 2019, 247, 266-276. [CrossRef] [PubMed]

21. Wakkel, M.; Khiari, B.; Zagrouba, F. Textile Wastewater Treatment by Agro-Industrial Waste: Equilibrium Modelling, Thermodynamics and Mass Transfer Mechanisms of Cationic Dyes Adsorption onto Low-Cost Lignocellulosic Adsorbent. J. Taiwan Inst. Chem. Eng. 2019, 96, 439-452. [CrossRef] 
22. Nath, J.; Bag, S.; Bera, D.; Ray, L. Biotreatment of Malachite Green from Aqueous Solution and Simulated Textile Effluent by Growing Cells (Batch Mode) and Activated Sludge System. Groundw. Sustain. Dev. 2019, 8, 172-178. [CrossRef]

23. Bankole, P.O.; Adekunle, A.A.; Obidi, O.F.; Olukanni, O.D.; Govindwar, S.P. Degradation of Indigo Dye by a Newly Isolated Yeast, Diutina Rugosa from Dye Wastewater Polluted Soil. J. Environ. Chem. Eng. 2017, 5, 4639-4648. [CrossRef]

24. Deniz, F.; Karaman, S. Removal of an Azo-Metal Complex Textile Dye from Colored Aqueous Solutions Using an Agro-Residue. Microchem. J. 2011, 99, 296-302. [CrossRef]

25. Sanz Carbonell, J.F. Tratamiento de Aguas Textiles Industriales Mediante Fotocatálisis Solar y Reutilización en Nuevas Tinturas. Ph.D. Thesis, Universitat Politècnica de València, València, Spain, 2016.

26. Chorawalaa, K.K.; Mehta, M.J. Applications of Nanotechnology in Wastewater Treatment. Int. J. Innov. Emerg. Res. Eng. 2015, 2, 21-26.

27. Sayan, B.; Indranil, S.; Aniruddha, M.; Dhrubajyoti, C.; Uday, C.G.; Debashis, C. Role of Nanotechnology in Water Treatment and Purification: Potential Applications and Implications. Int. J. Chem. Sci. Technol. 2013, 3, 59.

28. Hua, M.; Zhang, S.; Pan, B.; Zhang, W.; Lv, L.; Zhang, Q. Heavy Metal Removal from Water/Wastewater by Nanosized Metal Oxides: A Review. J. Hazard. Mater. 2012, 211, 317-331. [CrossRef] [PubMed]

29. Kumar, R.; Chawla, J. Removal of Cadmium Ion from Water/Wastewater by Nano-Metal Oxides: A Review. Water Qual. Expo. Health 2014, 5, 215-226. [CrossRef]

30. Rajput, S.; Pittman, C.U., Jr.; Mohan, D. Magnetic Magnetite $\left(\mathrm{Fe}_{3} \mathrm{O}_{4}\right)$ Nanoparticle Synthesis and Applications for Lead $\left(\mathrm{Pb}^{2+}\right)$ and Chromium $\left(\mathrm{Cr}^{6+}\right)$ Removal from Water. J. Colloid Interface Sci. 2016, 468, 334-346. [CrossRef]

31. Cheriyamundath, S.; Vavilala, S.L. Nanotechnology-based Wastewater Treatment. Water Environ. J. 2021, 35, 123-132. [CrossRef]

32. Gupta, V.K.; Saleh, T.A. Sorption of Pollutants by Porous Carbon, Carbon Nanotubes and Fullerene-an Overview. Environ. Sci. Pollut. Res. 2013, 20, 2828-2843. [CrossRef]

33. Iannazzo, D.; Pistone, A.; Ziccarelli, I.; Espro, C.; Galvagno, S.; Giofré, S.V.; Romeo, R.; Cicero, N.; Bua, G.D.; Lanza, G. Removal of Heavy Metal Ions from Wastewaters Using Dendrimer-Functionalized Multi-Walled Carbon Nanotubes. Environ. Sci. Pollut. Res. 2017, 24, 14735-14747. [CrossRef] [PubMed]

34. Zhao, M.; Xu, Y.; Zhang, C.; Rong, H.; Zeng, G. New Trends in Removing Heavy Metals from Wastewater. Appl. Microbiol. Biotechnol. 2016, 100, 6509-6518. [CrossRef]

35. Pendergast, M.M.; Hoek, E.M. V A Review of Water Treatment Membrane Nanotechnologies. Energy Environ. Sci. 2011, 4, 1946-1971. [CrossRef]

36. Zhang, L.; Chen, B.; Ghaffar, A.; Zhu, X. Nanocomposite Membrane with Polyethylenimine-Grafted Graphene Oxide as a Novel Additive to Enhance Pollutant Filtration Performance. Environ. Sci. Technol. 2018, 52, 5920-5930. [CrossRef] [PubMed]

37. Peng, K.; Yang, H. Carbon Hybridized Montmorillonite Nanosheets: Preparation, Structural Evolution and Enhanced Adsorption Performance. Chem. Commun. 2017, 53, 6085-6088. [CrossRef] [PubMed]

38. Sharma, V.; Sharma, A. Nanotechnology: An Emerging Future Trend in Wastewater Treatment with Its Innovative Products and Processes. Nanotechnology 2012, 1. Available online: https:/ / www.semanticscholar.org/paper/Nanotechnology-\%3A-An-EmergingFuture-Trend-in-with-Sharma-Sharma/c4a78b0b044126e137ad6cf2daf63590c15ab49d (accessed on 22 November 2021).

39. Wang, J.-C.; Lou, H.-H.; Xu, Z.-H.; Cui, C.-X.; Li, Z.-J.; Jiang, K.; Zhang, Y.-P.; Qu, L.-B.; Shi, W. Natural Sunlight Driven Highly Efficient Photocatalysis for Simultaneous Degradation of Rhodamine B and Methyl Orange Using I/C Codoped TiO 2 Photocatalyst. J. Hazard. Mater. 2018, 360, 356-363. [CrossRef] [PubMed]

40. Zhang, X.; Ma, Y.; Xi, L.; Zhu, G.; Li, X.; Shi, D.; Fan, J. Highly Efficient Photocatalytic Removal of Multiple Refractory Organic Pollutants by $\mathrm{BiVO}_{4} / \mathrm{CH}_{3} \mathrm{COO}(\mathrm{BiO})$ Heterostructured Nanocomposite. Sci. Total Environ. 2019, 647, 245-254. [CrossRef]

41. Ramakrishna, K.R.; Viraraghavan, T. Dye Removal Using Low Cost Adsorbents. Water Sci. Technol. 1997, 36, 189-196. [CrossRef]

42. Clarke, E.A.; Anliker, R. Organic Dyes and Pigments. In Anthropogenic compounds; Springer: Berlin/Heidelberg, Germany, 1980; pp. 181-215.

43. Zollinger, H. Color Chemistry: Syntheses, Properties and Applications of Organic Dyes and Pigments, 3rd ed.; Wiley-VHCA: Zurich, Switzerland, 2003; pp. 15-65, ISBN 3-906390-23-3.

44. Akarslan, F.; Demiralay, H. Effects of Textile Materials Harmful to Human Health. Acta Phys. Pol. A 2015, 128, 407-409. [CrossRef]

45. Anliker, R. Color Chemistry and the Environment. Ecotoxicol. Environ. Saf. 1977, 1, 211-237. [CrossRef]

46. Clement, R.E.; Koester, C.J.; Eiceman, G.A. Environmental Analysis. Anal. Chem. 1993, 65, 85-116. [CrossRef]

47. Tchobanoglous, G.; Burton, F.L.; Stensel, H.D. Wastewater Engineering. Management 1991, 7, 4.

48. Pollard, S.J.T.; Fowler, G.D.; Sollars, C.J.; Perry, R. Low-Cost Adsorbents for Waste and Wastewater Treatment: A Review. Sci. Total Environ. 1992, 116, 31-52. [CrossRef]

49. Andreo-Martínez, P.; García-Martínez, N.; Almela, L. Domestic Wastewater Depuration Using a Horizontal Subsurface Flow Constructed Wetland and Theoretical Surface Optimization: A Case Study under Dry Mediterranean Climate. Water 2016, 8, 434. [CrossRef]

50. Cossu, R.; Fantinato, G.; Pivato, A.; Sandon, A. Further Steps in the Standardization of BOD $5 /$ COD Ratio as a Biological Stability Index for MSW. Waste Manag. 2017, 68, 16-23. [CrossRef] [PubMed]

51. Cossu, R.; Lai, T.; Sandon, A. Standardization of $\mathrm{BOD}_{5} / \mathrm{COD}$ Ratio as a Biological Stability Index for MSW. Waste Manag. 2012, 32, 1503-1508. [CrossRef]

52. Cazaudehore, G.; Schraauwers, B.; Peyrelasse, C.; Lagnet, C.; Monlau, F. Determination of Chemical Oxygen Demand of Agricultural Wastes by Combining Acid Hydrolysis and Commercial COD Kit Analysis. J. Environ. Manag. 2019, 250, 109464. [CrossRef] 
53. Ghorbani, M.; Salem, S. Solar Treatment of Sewage Discharged from Industrial Estate for Reduction of Chemical Oxygen Demand over Degussa P-25 Titania. Chemosphere 2020, 129123. [CrossRef] [PubMed]

54. Fronczyk, J.; Radziemska, M.; Dynowski, P.; Mazur, Z.; Bazydło, M. Quality of Water in the Road Drainage Systems in the Warsaw Agglomeration, Poland. Water 2016, 8, 429. [CrossRef]

55. Ma, J.; Liu, L.; Xue, Q.; Yang, Y.; Zhang, Y.; Fei, X. A Systematic Assessment of Aeration Rate Effect on Aerobic Degradation of Municipal Solid Waste Based on Leachate Chemical Oxygen Demand Removal. Chemosphere 2021, 263, 128218. [CrossRef] [PubMed]

56. Patel, N.; Ruparelia, J.; Barve, J. Prediction of Total Suspended Solids Present in Effluent of Primary Clarifier of Industrial Common Effluent Treatment Plant: Mechanistic and Fuzzy Approach. J. Water Process Eng. 2020, 34, 101146. [CrossRef]

57. Crespi, M. Reutilización de Los Efluentes Textiles En Europa. Boletín INTEXTER 1989, 96, 87-106.

58. Ren, J.; Zhang, A.; Wang, X. Jo Ur Na 1 P Re. Pharmacol. Res. 2020, 104743. [CrossRef]

59. Skuse, C.; Gallego-Schmid, A.; Azapagic, A.; Gorgojo, P. Can Emerging Membrane-Based Desalination Technologies Replace Reverse Osmosis? Desalination 2020, 114844. [CrossRef]

60. Rahimi, B.; Shirvani, H.; Asghar, A.; Farhadi, F. A Feasibility Study of Solar-Powered Reverse Osmosis Processes Kingdom of Saudi Arabia. Desalination 2020, 114885. [CrossRef]

61. Ozbey-Unal, B.; Omwene, P.I.; Yagcioglu, M.; Balcik-Canbolat, Ç.; Karagunduz, A.; Keskinler, B.; Dizge, N. Treatment of Organized Industrial Zone Wastewater by Microfiltration/Reverse Osmosis Membrane Process for Water Recovery: From Lab to Pilot Scale. J. Water Process Eng. 2020, 38, 101646. [CrossRef]

62. Lebron, Y.A.R.; Moreira, V.R.; Furtado, T.P.B.; da Silva, S.C.; Lange, L.C.; Amaral, M.C.S. Vinasse Treatment Using Hybrid TanninBased Coagulation-Microfiltration-Nanofiltration Processes: Potential Energy Recovery, Technical and Economic Feasibility Assessment. Sep. Purif. Technol. 2020, 248, 117152. [CrossRef]

63. Manouchehri, M.; Kargari, A. Water Recovery from Laundry Wastewater by the Cross Flow Microfiltration Process: A Strategy for Water Recycling in Residential Buildings. J. Clean. Prod. 2017, 168, 227-238. [CrossRef]

64. Ağtaş, M.; Yılmaz, Ö.; Dilaver, M.; Alp, K.; Koyuncu, İ. Hot Water Recovery and Reuse in Textile Sector with Pilot Scale Ceramic Ultrafiltration/Nanofiltration Membrane System. J. Clean. Prod. 2020, 256, 120359. [CrossRef]

65. Selvaraj, H.; Chandrasekaran, K.; Murugan, R.; Sundaram, M. An Integrated Biological and Electrochemical Process for Recovery of Sulfur from an Industrial Effluent Contaminated Pond Water and Its Preliminary Application in High Performance Battery. Sep. Purif. Technol. 2017, 180, 133-141. [CrossRef]

66. Ma, C.; Pei, S.; You, S. Closed Bipolar Electrode for Decoupled Electrochemical Water Decontamination and Hydrogen Recovery. Electrochem. Commun. 2019, 109, 106611. [CrossRef]

67. Chen, P.; Yin, D.; Song, P.; Liu, Y.; Cai, L.; Wang, H.; Zhang, L. Demulsification and Oil Recovery from Oil-in-Water Cutting Fluid Wastewater Using Electrochemical Micromembrane Technology. J. Clean. Prod. 2020, 244, 118698. [CrossRef]

68. Buscio Olivera, V. Tratamiento y Reutilización de Efluentes de La Industria Textil Mediante Técnicas de Membranas. TDX (Tesis Dr. en Xarxa). Universitat Politècnica de Catalunya. Departament d'Enginyeria Tèxtil i Paperera. 2015. Available online: http: / /hdl.handle.net/2117/96008 (accessed on 22 November 2021).

69. Cheng, D.; Liu, Y.; Ngo, H.H.; Guo, W.; Chang, S.W.; Nguyen, D.D.; Zhang, S.; Luo, G.; Liu, Y. A Review on Application of Enzymatic Bioprocesses in Animal Wastewater and Manure Treatment. Bioresour. Technol. 2020, 313, 123683. [CrossRef]

70. He, H.; Zhang, X.; Yang, C.; Zeng, G.; Li, H.; Chen, Y. Treatment of Organic Wastewater Containing High Concentration of Sulfate by Crystallization-Fenton-SBR. J. Environ. Eng. 2018, 144, 4018041. [CrossRef]

71. Shao, J.; Cheng, Y.; Yang, C.; Zeng, G.; Liu, W.; Jiao, P.; He, H. Efficient Removal of Naphthalene-2-ol from Aqueous Solutions by Solvent Extraction. J. Environ. Sci. 2016, 47, 120-129. [CrossRef] [PubMed]

72. Ordonez, D.; Valencia, A.; Chang, N.-B.; Wanielista, M.P. Synergistic Effects of Aluminum/Iron Oxides and Clay Minerals on Nutrient Removal and Recovery in Water Filtration Media. J. Clean. Prod. 2020, 275, 122728. [CrossRef]

73. Hube, S.; Eskafi, M.; Hrafnkelsdóttir, K.F.; Bjarnadóttir, B.; Bjarnadóttir, M.Á.; Axelsdóttir, S.; Wu, B. Direct Membrane Filtration for Wastewater Treatment and Resource Recovery: A Review. Sci. Total Environ. 2020, 710, 136375. [CrossRef] [PubMed]

74. El-Diasty, A.I.; Ragab, A.M. Applications of Nanotechnology in the oil \& gas industry: Lastest trends wordwilde \& future challenges in Egypt. In Porceedings of the North Africa Technical Conference and Exhibition, Cairo, Egypt, 15 April 2013; One Petro: Cairo, Egypt, 2013; Paper Number SPE-164716-MS. [CrossRef]

75. Yang, Y.; Han, S.; Fan, Q.; Ugbolue, S.C. Nanoclay and Modified Nanoclay as Sorbents for Anionic, Cationic and Nonionic Dyes. Text. Res. J. 2005, 75, 622-627. [CrossRef]

76. López Arbeloa, F.; Martínez Martínez, V.; Bañuelos Prieto, J.; López Arbeloa, I. Adsorption of Rhodamine 3B Dye on Saponite Colloidal Particles in Aqueous Suspensions. Langmuir 2002, 18, 2658-2664. [CrossRef]

77. Yang, S.; Gao, M.; Luo, Z. Adsorption of 2-Naphthol on the Organo-Montmorillonites Modified by Gemini Surfactants with Different Spacers. Chem. Eng. J. 2014, 256, 39-50. [CrossRef]

78. Luo, Z.; Gao, M.; Ye, Y.; Yang, S. Modification of Reduced-Charge Montmorillonites by a Series of Gemini Surfactants: Characterization and Application in Methyl Orange Removal. Appl. Surf. Sci. 2015, 324, 807-816. [CrossRef]

79. Zhu, T.T.; Zhou, C.H.; Kabwe, F.B.; Wu, Q.Q.; Li, C.S.; Zhang, J.R. Exfoliation of Montmorillonite and Related Properties of Clay/Polymer Nanocomposites. Appl. Clay Sci. 2019, 169, 48-66. [CrossRef] 
80. Zheng, L.; Xu, H.; Rutqvist, J.; Reagan, M.; Birkholzer, J.; Villar, M.V.; Fernández, A.M. The Hydration of Bentonite Buffer Material Revealed by Modeling Analysis of a Long-Term in Situ Test. Appl. Clay Sci. 2020, 185, 105360. [CrossRef]

81. Gupta, V.K.; Agarwal, S.; Olgun, A.; Demir, H.İ.; Yola, M.L.; Atar, N. Adsorptive Properties of Molasses Modified Boron Enrichment Waste Based Nanoclay for Removal of Basic Dyes. J. Ind. Eng. Chem. 2016, 34, 244-249. [CrossRef]

82. Carretero, M.I.; Pozo, M.; Sánchez, C.; García, F.J.; Medina, J.A.; Bernabé, J.M. Comparison of Saponite and Montmorillonite Behaviour during Static and Stirring Maturation with Seawater for Pelotherapy. Appl. Clay Sci. 2007, 36, 161-173. [CrossRef]

83. Taleb, K.; Pillin, I.; Grohens, Y.; Saidi-Besbes, S. Gemini Surfactant Modified Clays: Effect of Surfactant Loading and Spacer Length. Appl. Clay Sci. 2018, 161, 48-56. [CrossRef]

84. Ngulube, T.; Gumbo, J.R.; Masindi, V.; Maity, A. An Update on Synthetic Dyes Adsorption onto Clay Based Minerals: A State-ofArt Review. J. Environ. Manag. 2017, 191, 35-57. [CrossRef] [PubMed]

85. Dolez, P.I. Nanomaterials Definitions, Classifications, and Applications. Nanoengineering 2015, 3-40. [CrossRef]

86. Rasouli, F.; Aber, S.; Salari, D.; Khataee, A.R. Optimized Removal of Reactive Navy Blue SP-BR by Organo-Montmorillonite Based Adsorbents through Central Composite Design. Appl. Clay Sci. 2014, 87, 228-234. [CrossRef]

87. Zayed, A.M.; Abdel Wahed, M.S.M.; Mohamed, E.A.; Sillanpää, M. Insights on the Role of Organic Matters of Some Egyptian Clays in Methyl Orange Adsorption: Isotherm and Kinetic Studies. Appl. Clay Sci. 2018, 166, 49-60. [CrossRef]

88. Stagnaro, S.M.; Volzone, C.; Huck, L. Nanoclay as Adsorbent: Evaluation for Removing Dyes Used in the Textile Industry. Procedia Mater. Sci. 2015, 8, 586-591. [CrossRef]

89. Nyankson, E.; Agyei-Tuffour, B.; Annan, E.; Yaya, A.; Mensah, B.; Onwona-Agyeman, B.; Amedalor, R.; Kwaku-Frimpong, B.; Efavi, J.K. $\mathrm{Ag}_{2} \mathrm{CO}_{3}$-Halloysite Nanotubes Composite with Enhanced Removal Efficiency for Water Soluble Dyes. Heliyon 2019, 5, e01969. [CrossRef] [PubMed]

90. Yang, Q.; Gao, M.; Luo, Z.; Yang, S. Enhanced Removal of Bisphenol A from Aqueous Solution by Organo-Montmorillonites Modified with Novel Gemini Pyridinium Surfactants Containing Long Alkyl Chain. Chem. Eng. J. 2016, 285, 27-38. [CrossRef]

91. Selvitepe, N.; Balbay, A.; Saka, C. Optimisation of Sepiolite Clay with Phosphoric Acid Treatment as Support Material for CoB Catalyst and Application to Produce Hydrogen from the $\mathrm{NaBH}_{4}$ Hydrolysis. Int. J. Hydrogen Energy 2019, 44, 16387-16399. [CrossRef]

92. Daraei, P.; Madaeni, S.S.; Salehi, E.; Ghaemi, N.; Ghari, H.S.; Khadivi, M.A.; Rostami, E. Novel Thin Film Composite Membrane Fabricated by Mixed Matrix Nanoclay/Chitosan on PVDF Microfiltration Support: Preparation, Characterization and Performance in Dye Removal. J. Membr. Sci. 2013, 436, 97-108. [CrossRef]

93. Olvera, R.C.; Silva, S.L.; Robles-Belmont, E.; Lau, E.Z. Review of Nanotechnology Value Chain for Water Treatment Applications in Mexico. Resour. Technol. 2017, 3, 1-11. [CrossRef]

94. Kausar, A.; Iqbal, M.; Javed, A.; Aftab, K.; Nazli, Z.-H.; Bhatti, H.N.; Nouren, S. Dyes Adsorption Using Clay and Modified Clay: A Review. J. Mol. Liq. 2018, 256, 395-407. [CrossRef]

95. Darwish, A.A.A.; Rashad, M.; AL-Aoh, H.A. Methyl Orange Adsorption Comparison on Nanoparticles: Isotherm, Kinetics, and Thermodynamic Studies. Dye. Pigment. 2019, 160, 563-571. [CrossRef]

96. Santhosh, C.; Velmurugan, V.; Jacob, G.; Jeong, S.K.; Grace, A.N.; Bhatnagar, A. Role of Nanomaterials in Water Treatment Applications: A Review. Chem. Eng. J. 2016, 306, 1116-1137. [CrossRef]

97. Schoonheydt, R.A.; Heughebaert, L. Clay adsorbed dyes: Methylene blue on laponite. Clay Miner. 1992, 27, 91-100. [CrossRef]

98. Yagub, M.T.; Sen, T.K.; Afroze, S.; Ang, H.M. Dye and Its Removal from Aqueous Solution by Adsorption: A Review. Adv. Colloid Interface Sci. 2014, 209, 172-184. [CrossRef] [PubMed]

99. Anjum, M.; Miandad, R.; Waqas, M.; Gehany, F.; Barakat, M.A. Remediation of Wastewater Using Various Nano-Materials. Arab. J. Chem. 2016. [CrossRef]

100. Liang, Y.; Li, H. A Comparison of Trimeric Surfactant Intercalated Montmorillonite with Its Gemini Modified One: Characterization and Application in Methyl Orange Removal. J. Mol. Liq. 2017, 227, 139-146. [CrossRef]

101. Vanamudan, A.; Pamidimukkala, P. Chitosan, Nanoclay and Chitosan-Nanoclay Composite as Adsorbents for Rhodamine-6G and the Resulting Optical Properties. Int. J. Biol. Macromol. 2015, 74, 127-135. [CrossRef] [PubMed]

102. Fontaine, F.; Christidis, G.E.; Yans, J.; Hollanders, S.; Hoffman, A.; Fagel, N. Characterization and Origin of Two Fe-Rich Bentonites from Westerwald (Germany). Appl. Clay Sci. 2020, 187, 105444. [CrossRef]

103. Topuz, F.; Uyar, T. Electrospinning of Nanocomposite Nanofibers from Cyclodextrin and Laponite. Compos. Commun. 2019, $12,33-38$. [CrossRef]

104. Zhou, C.H.; Zhou, Q.; Wu, Q.Q.; Petit, S.; Jiang, X.C.; Xia, S.T.; Li, C.S.; Yu, W.H. Modification, Hybridization and Applications of Saponite: An Overview. Appl. Clay Sci. 2019, 168, 136-154. [CrossRef]

105. De Gisi, S.; Lofrano, G.; Grassi, M.; Notarnicola, M. Characteristics and Adsorption Capacities of Low-Cost Sorbents for Wastewater Treatment: A Review. Sustain. Mater. Technol. 2016, 9, 10-40. [CrossRef]

106. Colletti, C.G.; Massaro, M.; Lazzara, G.; Cavallaro, G.; Milioto, S.; Pibiri, I.; Noto, R.; Riela, S. Synthesis, Characterization and Study of Covalently Modified Triazole LAPONITE ${ }^{\circledR}$ Edges. Appl. Clay Sci. 2020, 187, 105489. [CrossRef]

107. El-Zahhar, A.A.; Awwad, N.S.; El-Katori, E.E. Removal of Bromophenol Blue Dye from Industrial Waste Water by Synthesizing Polymer-Clay Composite. J. Mol. Liq. 2014, 199, 454-461. [CrossRef]

108. Khodami, S.; Mehdipour-Ataei, S.; Babanzadeh, S. Preparation, Characterization, and Performance Evaluation of Sepiolite-Based Nanocomposite Membrane for Desalination. J. Ind. Eng. Chem. 2020, 82, 164-172. [CrossRef] 
109. Mittal, H.; Babu, R.; Dabbawala, A.A.; Stephen, S.; Alhassan, S.M. Zeolite-Y Incorporated Karaya Gum Hydrogel Composites for Highly Effective Removal of Cationic Dyes. Colloids Surfaces A Physicochem. Eng. Asp. 2020, 586, 124161. [CrossRef]

110. Micó Vicent, B.; Martinez Verdu, F.M.; Gilabert Perez, J.E. Optimización de La Síntesis de Nanopigmentos de Origen Natural Para Biopolímeros Mediante El Uso Del Diseño de Experimentos. Ph.D. Thesis, Universitat Politècnica de València, 2015. Available online: http:/ / hdl.handle.net/10251/59449 (accessed on 22 November 2021).

111. Chong, A.S.; Manan, M.A.; Idris, A.K. Readiness of Lignosulfonate Adsorption onto Montmorillonite. Colloids Surfaces A Physicochem. Eng. Asp. 2021, 628, 127318. [CrossRef]

112. Alexandre, M.; Dubois, P. Polymer-Layered Silicate Nanocomposites: Preparation, Properties and Uses of a New Class of Materials. Mater. Sci. Eng. R Rep. 2000, 28, 1-63. [CrossRef]

113. Emmerich, K.; Kahr, G. The Cis-and Trans-Vacant Variety of a Montmorillonite: An Attempt to Create a Model Smectite. Appl. Clay Sci. 2001, 20, 119-127. [CrossRef]

114. Li, J.; Cai, J.; Zhong, L.; Cheng, H.; Wang, H.; Ma, Q. Adsorption of Reactive Red 136 onto Chitosan/Montmorillonite Intercalated Composite from Aqueous Solution. Appl. Clay Sci. 2019, 167, 9-22. [CrossRef]

115. Gireeshkumar, T.R.; Mathew, D.; Udayakrishnan, P.B.; Shameem, K.; KP, F.F.; Furtado, C.M.; Deepulal, P.M.; Nair, M.; Balachandran, K.K. Montmorillonite and Phosphorus Enrichment in Sediments as the Causative Factor for Mud Bank Formation along the Southwest Coast of India. Reg. Stud. Mar. Sci. 2020, 40, 101517. [CrossRef]

116. Zheng, R.; Liu, D.; Tang, J.; Song, Q.; Yao, Q. Analysis of Montmorillonite Affecting Coke Formation during the Thermal Conversion of Heavy Oil. Fuel 2020, 288, 119687. [CrossRef]

117. Yan, H.; Zhang, Z. Effect and Mechanism of Cation Species on the Gel Properties of Montmorillonite. Colloids Surfaces A Physicochem. Eng. Asp. 2020, 611, 125824. [CrossRef]

118. Hojiyev, R.; Ulcay, Y.; Çelik, M.S.; Carty, W.M. Effect of CEC Coverage of Hexadecyltributylphosphonium Modified Montmorillonite on Polymer Compatibility. Appl. Clay Sci. 2017, 141, 204-211. [CrossRef]

119. Manning, D.A.C. Handbook of Clay Science (Developments in Clay Science, 1); Bergaya, F., Theng, B.K.G., Lagaly, G., Eds.; Elsevier: Oxford, UK, 2007.

120. Capková, P.; Driessen, R.A.J.; Schenk, H.; Weiss, Z. Interlayer Porosity in Montmorillonite Intercalated with Keggin-like Cation Studied by Molecular Mechanics Simulation. Mol. Model. Annu. 1997, 3, 467-472. [CrossRef]

121. Vazquez, A.; López, M.; Kortaberria, G.; Martín, L.; Mondragon, I. Modification of Montmorillonite with Cationic Surfactants. Thermal and Chemical Analysis Including CEC Determination. Appl. Clay Sci. 2008, 41, 24-36. [CrossRef]

122. Zhu, H.Y.; Gao, W.H.; Vansant, E.F. The Porosity and Water Adsorption of Alumina Pillared Montmorillonite. J. Colloid Interface Sci. 1995, 171, 377-385. [CrossRef]

123. Laird, D.A.; Shang, C. Relationship between Cation Exchange Selectivity and Crystalline Swelling in Expanding 2: 1 Phyllosilicates. Clays Clay Miner. 1997, 45, 681-689. [CrossRef]

124. Wang, C.-C.; Juang, L.-C.; Hsu, T.-C.; Lee, C.-K.; Lee, J.-F.; Huang, F.-C. Adsorption of Basic Dyes onto Montmorillonite. J. Colloid Interface Sci. 2004, 273, 80-86. [CrossRef] [PubMed]

125. Fahn, R.; Fenderl, K. Reaction Products of Organic Dye Molecules with Acid-Treated Montmorillonite. Clay Miner. 1983, 18, 447-458. [CrossRef]

126. Mishael, Y.G.; Rytwo, G.; Nir, S.; Crespin, M.; Annabi-Bergaya, F.; Van Damme, H. Interactions of Monovalent Organic Cations with Pillared Clays. J. Colloid Interface Sci. 1999, 209, 123-128. [CrossRef]

127. Penner, D.; Lagaly, G. Influence of Organic and Inorganic Salts on the Coagulation of Montmorillonite Dispersions. Clays Clay Miner. 2000, 48, 246-255. [CrossRef]

128. Janek, M.; Lagaly, G. Proton Saturation and Rheological Properties of Smectite Dispersions. Appl. Clay Sci. 2001, 19, 121-130. [CrossRef]

129. Antúnez-García, J.; Galván, D.H.; Petranovskii, V.; Murrieta-Rico, F.N.; Yocupicio-Gaxiola, R.I.; Shelyapina, M.G.; FuentesMoyado, S. The Effect of Chemical Composition on the Properties of LTA Zeolite: A Theoretical Study. Comput. Mater. Sci. 2021, 196. [CrossRef]

130. Khaleque, A.; Alam, M.M.; Hoque, M.; Mondal, S.; Haider, J.B.; Xu, B.; Johir, M.A.H.; Karmakar, A.K.; Zhou, J.L.; Ahmed, M.B.; et al. Zeolite Synthesis from Low-Cost Materials and Environmental Applications: A Review. Environ. Adv. 2020, 2, 100019. [CrossRef]

131. Si, D.; Zhu, M.; Sun, X.; Xue, M.; Li, Y.; Wu, T.; Gui, T.; Kumakiri, I.; Chen, X.; Kita, H. Formation Process and Pervaporation of High Aluminum ZSM-5 Zeolite Membrane with Fluoride-Containing and Organic Template-Free Gel. Sep. Purif. Technol. 2021, 257, 117963. [CrossRef]

132. Lo, A.Y.; Taghipour, F. Review and Prospects of Microporous Zeolite Catalysts for $\mathrm{CO}_{2}$ Photoreduction. Appl. Mater. Today 2021, 23, 101042. [CrossRef]

133. He, C.; Zhang, X.; Yu, J.; Xiang, Y.; Deng, L.; Zhao, S.; Gao, J.; Yuan, Y.; Lei, Y. Study on Adsorption Performance and Mechanism of Cr (VI) by Zn-LDHs Coating on Zeolites and Quartz Sands. Acta Sci. Circumstantiae 2019, 39, $399-409$.

134. Wang, C.; Cao, L.; Huang, J. Influences of Acid and Heat Treatments on the Structure and Water Vapor Adsorption Property of Natural Zeolite. Surf. Interface Anal. 2017, 49, 1249-1255. [CrossRef]

135. Probst, J.; Outram, J.G.; Couperthwaite, S.J.; Millar, G.J.; Kaparaju, P. Sustainable Ammonium Recovery from Wastewater: Improved Synthesis and Performance of Zeolite N Made from Kaolin. Microporous Mesoporous Mater. 2021, 316, 110918. [CrossRef]

136. Zhu, J.; Wang, N. Applications of Natural Zeolites to Environmental Protection. Acta Mineral. Sin. 2003, 23, 250-254. 
137. Kaijun, W.; Wenyan, H.E.; Kuo, F. Analysis of the Application of Typical Ion Exchange Water Treatment Technology in Low Concentration Ammonia Nitrogen Recovery. Chin. J. Environ. Eng. 2019, 13, 2285-2301.

138. Sharma, R.; Segato, T.; Delplancke, M.-P.; Terryn, H.; Baron, G.V.; Denayer, J.F.M.; Cousin-Saint-Remi, J. Hydrogen Chloride Removal from Hydrogen Gas by Adsorption on Hydrated Ion-Exchanged Zeolites. Chem. Eng. J. 2020, 381, 122512. [CrossRef]

139. Shi, Y.; Sun, K. Preparation of Diphenylcarbazide-Directed CdSe Quantum Dots and Selective Determination for Cr (VI). J. Wuhan Univ. Technol. Sci. Ed. 2016, 31, 972-976. [CrossRef]

140. Breck, D.W. Zeolite Molecular Sieves: Structure, Chemistry and Use; Krieger; John Wiley \& Sons: New York, NY, USA, 1984; ISBN 0898746485.

141. Wajima, T.; Yoshizuka, K.; Hirai, T.; Ikegami, Y. Synthesis of Zeolite X from Waste Sandstone Cake Using Alkali Fusion Method. Mater. Trans. 2008, 49, 612-618. [CrossRef]

142. Shoppert, A.A.; Loginova, I.V.; Chaikin, L.I.; Rogozhnikov, D.A. Alkali Fusion-Leaching Method for Comprehensive Processing of Fly Ash. KnE Mater. Sci. 2017, 89-96. [CrossRef]

143. Tsujiguchi, M.; Kobashi, T.; Oki, M.; Utsumi, Y.; Kakimori, N.; Nakahira, A. Synthesis and Characterization of Zeolite A from Crushed Particles of Aluminoborosilicate Glass Used in LCD Panels. J. Asian Ceram. Soc. 2014, 2, 27-32. [CrossRef]

144. Perot, G.; Guisnet, M. Advantages and Disadvantages of Zeolites as Catalysts in Organic Chemistry. J. Mol. Catal. 1990, 61, 173-196. [CrossRef]

145. Parades-Aguilar, J.; Reyes-Martínez, V.; Bustamante, G.; Almendáriz-Tapia, F.J.; Martínez-Meza, G.; Vílchez-Vargas, R.; Link, A.; Certucha-Barragán, M.T.; Calderón, K. Removal of Nickel (II) from Wastewater Using a Zeolite-Packed Anaerobic Bioreactor: Bacterial Diversity and Community Structure Shifts. J. Environ. Manag. 2021, 279, 111558. [CrossRef] [PubMed]

146. Saqib, N.U.; Adnan, R.; Rahim, M.; Khan, A. Low-Cost Zeolite/ $\mathrm{TiO}_{2}$ Composite for the Photocatalytically Enhanced Adsorption of $\mathrm{Cd}^{2+}$ from Aqueous Solution. J. Iran. Chem. Soc. 2021, 18, 2165-2180. [CrossRef]

147. Lvov, Y.M.; DeVilliers, M.M.; Fakhrullin, R.F. The Application of Halloysite Tubule Nanoclay in Drug Delivery. Expert Opin. Drug Deliv. 2016, 13, 977-986. [CrossRef] [PubMed]

148. Liu, M.; Jia, Z.; Jia, D.; Zhou, C. Recent Advance in Research on Halloysite Nanotubes-Polymer Nanocomposite. Prog. Polym. Sci. 2014, 39, 1498-1525. [CrossRef]

149. Lazaratou, C.V.; Panagiotaras, D.; Panagopoulos, G.; Pospíšil, M.; Papoulis, D. Ca Treated Palygorskite and Halloysite Clay Minerals for Ferrous Iron $\left(\mathrm{Fe}^{+2}\right)$ Removal from Water Systems. Environ. Technol. Innov. 2020, 19, 100961. [CrossRef]

150. Van Ranst, E.; Kips, P.; Mbogoni, J.; Mees, F.; Dumon, M.; Delvaux, B. Halloysite-Smectite Mixed-Layered Clay in Fluvio-Volcanic Soils at the Southern Foot of Mount Kilimanjaro, Tanzania. Geoderma 2020, 375, 114527. [CrossRef]

151. Zhao, N.; Liu, Y.; Zhao, X.; Song, H. Liquid Crystal Self-Assembly of Halloysite Nanotubes in Ionic Liquids: A Novel Soft Nanocomposite Ionogel Electrolyte with High Anisotropic Ionic Conductivity and Thermal Stability. Nanoscale 2016, 8, 1545-1554. [CrossRef]

152. Lazzara, G.; Cavallaro, G.; Panchal, A.; Fakhrullin, R.; Stavitskaya, A.; Vinokurov, V.; Lvov, Y. An Assembly of Organic-Inorganic Composites Using Halloysite Clay Nanotubes. Curr. Opin. Colloid Interface Sci. 2018, 35, 42-50. [CrossRef]

153. Yendluri, R.; Otto, D.P.; De Villiers, M.M.; Vinokurov, V.; Lvov, Y.M. Application of Halloysite Clay Nanotubes as a Pharmaceutical Excipient. Int. J. Pharm. 2017, 521, 267-273. [CrossRef] [PubMed]

154. Yuan, P.; Tan, D.; Annabi-Bergaya, F. Properties and Applications of Halloysite Nanotubes: Recent Research Advances and Future Prospects. Appl. Clay Sci. 2015, 112, 75-93. [CrossRef]

155. Pasbakhsh, P.; Churchman, G.J.; Keeling, J.L. Characterisation of Properties of Various Halloysites Relevant to Their Use as Nanotubes and Microfibre Fillers. Appl. Clay Sci. 2013, 74, 47-57. [CrossRef]

156. Makaremi, M.; Pasbakhsh, P.; Cavallaro, G.; Lazzara, G.; Aw, Y.K.; Lee, S.M.; Milioto, S. Effect of Morphology and Size of Halloysite Nanotubes on Functional Pectin Bionanocomposites for Food Packaging Applications. ACS Appl. Mater. Interfaces 2017, 9, 17476-17488. [CrossRef]

157. Cavallaro, G.; Chiappisi, L.; Pasbakhsh, P.; Gradzielski, M.; Lazzara, G. A Structural Comparison of Halloysite Nanotubes of Different Origin by Small-Angle Neutron Scattering (SANS) and Electric Birefringence. Appl. Clay Sci. 2018, 160, 71-80. [CrossRef]

158. Agafonov, A.V.; Kudryakova, N.O.; Ramenskaya, L.M.; Grishina, E.P. The Confinement and Anion Type Effect on the Physicochemical Properties of Ionic Liquid/Halloysite Nanoclay Ionogels. Arab. J. Chem. 2020, 13, 9090-9104. [CrossRef]

159. Blagojević, B.; Četojević-Simin, D.; Parisi, F.; Lazzara, G.; Popović, B.M. Halloysite Nanotubes as a Carrier of Cornelian Cherry (Cornus Mas L.) Bioactives. Lwt 2020, 134, 110247. [CrossRef]

160. Zhang, B.; Yuan, P.; Guo, H.; Deng, L.; Li, Y.; Li, L.; Wang, Q.; Liu, D. Effect of Curing Conditions on the Microstructure and Mechanical Performance of Geopolymers Derived from Nanosized Tubular Halloysite. Constr. Build. Mater. 2020, 121186. [CrossRef]

161. Luo, P.; Zhao, Y.; Zhang, B.; Liu, J.; Yang, Y.; Liu, J. Study on the Adsorption of Neutral Red from Aqueous Solution onto Halloysite Nanotubes. Water Res. 2010, 44, 1489-1497. [CrossRef] [PubMed]

162. Liu, W.; Fizir, M.; Hu, F.; Li, A.; Hui, X.; Zha, J.; He, H. Mixed Hemimicelle Solid-Phase Extraction Based on Magnetic Halloysite Nanotubes and Ionic Liquids for the Determination and Extraction of Azo Dyes in Environmental Water Samples. J. Chromatogr. A 2018, 1551, 10-20. [CrossRef]

163. Zhao, M.; Liu, P. Adsorption Behavior of Methylene Blue on Halloysite Nanotubes. Microporous Mesoporous Mater. 2008, 112, 419-424. [CrossRef] 
164. Luo, P.; Zhang, B.; Zhao, Y.; Wang, J.; Zhang, H.; Liu, J. Removal of Methylene Blue from Aqueous Solutions by Adsorption onto Chemically Activated Halloysite Nanotubes. Korean J. Chem. Eng. 2011, 28, 800-807. [CrossRef]

165. Liu, Y.; Zheng, Y.; Wang, A. Response Surface Methodology for Optimizing Adsorption Process Parameters for Methylene Blue Removal by a Hydrogel Composite. Adsorpt. Sci. Technol. 2010, 28, 913-922. [CrossRef]

166. Liu, L.; Wan, Y.; Xie, Y.; Zhai, R.; Zhang, B.; Liu, J. The Removal of Dye from Aqueous Solution Using Alginate-Halloysite Nanotube Beads. Chem. Eng. J. 2012, 187, 210-216. [CrossRef]

167. Peng, Q.; Liu, M.; Zheng, J.; Zhou, C. Adsorption of Dyes in Aqueous Solutions by Chitosan-Halloysite Nanotubes Composite Hydrogel Beads. Microporous Mesoporous Mater. 2015, 201, 190-201. [CrossRef]

168. Jiang, L.; Zhang, C.; Wei, J.; Tjiu, W.; Pan, J.; Chen, Y.; Liu, T. Surface Modifications of Halloysite Nanotubes with Superparamagnetic $\mathrm{Fe}_{3} \mathrm{O}_{4}$ Nanoparticles and Carbonaceous Layers for Efficient Adsorption of Dyes in Water Treatment. Chem. Res. Chin. Univ. 2014, 30, 971-977. [CrossRef]

169. Nguyen, T.K.L.; Cao, X.T.; Park, C.; Lim, K.T. Preparation, Characterization and Application of Magnetic Halloysite Nanotubes for Dye Removal. Mol. Cryst. Liq. Cryst. 2017, 644, 153-159. [CrossRef]

170. Wan, X.; Zhan, Y.; Long, Z.; Zeng, G.; He, Y. Core@ Double-Shell Structured Magnetic Halloysite Nanotube Nano-Hybrid as Efficient Recyclable Adsorbent for Methylene Blue Removal. Chem. Eng. J. 2017, 330, 491-504. [CrossRef]

171. Farrokhi-Rad, M.; Mohammadalipour, M.; Shahrabi, T. Electrophoretically Deposited Halloysite Nanotubes Coating as the Adsorbent for the Removal of Methylene Blue from Aqueous Solution. J. Eur. Ceram. Soc. 2018, 38, 3650-3659. [CrossRef]

172. Liu, R.; Fu, K.; Zhang, B.; Mei, D.; Zhang, H.; Liu, J. Removal of Methyl Orange by Modified Halloysite Nanotubes. J. Dispers. Sci. Technol. 2012, 33, 711-718. [CrossRef]

173. Chen, H.; Zhao, J.; Wu, J.; Yan, H. Selective Desorption Characteristics of Halloysite Nanotubes for Anionic Azo Dyes. RSC Adv. 2014, 4, 15389-15393. [CrossRef]

174. Chen, H.; Yan, H.; Pei, Z.; Wu, J.; Li, R.; Jin, Y.; Zhao, J. Trapping Characteristic of Halloysite Lumen for Methyl Orange. Appl. Surf. Sci. 2015, 347, 769-776. [CrossRef]

175. Ferrarini, F.; Bonetto, L.R.; Crespo, J.S.; Giovanela, M. Removal of Congo Red Dye from Aqueous Solutions Using a HalloysiteMagnetite-Based Composite. Water Sci. Technol. 2016, 73, 2132-2142. [CrossRef] [PubMed]

176. Bessaha, F.; Mahrez, N.; Bendenia, S.; Kasmi, F.; Marouf-Khelifa, K.; Khelifa, A. Characterization and Spectroscopic Study of a Heat-Treated and Acid-Leached Halloysite Used in Congo Red Adsorption. Int. J. Intell. Eng. Syst. 2017, 10, 272-279. [CrossRef]

177. Fard, F.S.; Akbari, S.; Pajootan, E.; Arami, M. Enhanced Acidic Dye Adsorption onto the Dendrimer-Based Modified Halloysite Nanotubes. Desalin. Water Treat. 2016, 57, 26222-26239. [CrossRef]

178. Zango, Z.U.; Abu Bakar, N.H.H.; Tan, W.L.; Bakar, M.A. Enhanced Removal Efficiency of Methyl Red via the Modification of Halloysite Nanotubes by Copper Oxide. J. Dispers. Sci. Technol. 2018, 39, 148-154. [CrossRef]

179. Cavallaro, G.; Gianguzza, A.; Lazzara, G.; Milioto, S.; Piazzese, D. Alginate Gel Beads Filled with Halloysite Nanotubes. Appl. Clay Sci. 2013, 72, 132-137. [CrossRef]

180. Kiani, G.; Dostali, M.; Rostami, A.; Khataee, A.R. Adsorption Studies on the Removal of Malachite Green from Aqueous Solutions onto Halloysite Nanotubes. Appl. Clay Sci. 2011, 54, 34-39. [CrossRef]

181. Bessaha, F.; Marouf-Khelifa, K.; Batonneau-Gener, I.; Khelifa, A. Characterization and Application of Heat-Treated and AcidLeached Halloysites in the Removal of Malachite Green: Adsorption, Desorption, and Regeneration Studies. Desalin. Water Treat. 2016, 57, 14609-14621. [CrossRef]

182. Duan, J.; Liu, R.; Chen, T.; Zhang, B.; Liu, J. Halloysite Nanotube-Fe3O 4 Composite for Removal of Methyl Violet from Aqueous Solutions. Desalination 2012, 293, 46-52. [CrossRef]

183. Bonetto, L.R.; Ferrarini, F.; De Marco, C.; Crespo, J.S.; Guégan, R.; Giovanela, M. Removal of Methyl Violet 2B Dye from Aqueous Solution Using a Magnetic Composite as an Adsorbent. J. Water Process Eng. 2015, 6, 11-20. [CrossRef]

184. Tao, D.; Higaki, Y.; Ma, W.; Takahara, A. Halloysite Nanotube/Polyelectrolyte Hybrids as Adsorbents for the Quick Removal of Dyes from Aqueous Solution. Chem. Lett. 2015, 44, 1572-1574. [CrossRef]

185. Desai, S.; Pandey, A.; Dahiya, M.S. Application of Hallosysite Nanotubes in Removal of Auramine Y and Auramine O Dyes. Int. J. PharmTech. Res. 2017, 10, 62-76.

186. Khatri, N.; Tyagi, S.; Rawtani, D. Removal of Basic Dyes Auramine Yellow and Auramine O by Halloysite Nanotubes. Int. J. Environ. Waste Manag. 2016, 17, 44-59. [CrossRef]

187. Mudhoo, A.; Gautam, R.K.; Ncibi, M.C.; Zhao, F.; Garg, V.K.; Sillanpää, M. Green Synthesis, Activation and Functionalization of Adsorbents for Dye Sequestration. Environ. Chem. Lett. 2019, 17, 157-193. [CrossRef]

188. Riahi-Madvaar, R.; Taher, M.A.; Fazelirad, H. Synthesis and Characterization of Magnetic Halloysite-Iron Oxide Nanocomposite and Its Application for Naphthol Green B Removal. Appl. Clay Sci. 2017, 137, 101-106. [CrossRef]

189. Massaro, M.; Colletti, C.G.; Lazzara, G.; Guernelli, S.; Noto, R.; Riela, S. Synthesis and Characterization of Halloysite-Cyclodextrin Nanosponges for Enhanced Dyes Adsorption. ACS Sustain. Chem. Eng. 2017, 5, 3346-3352. [CrossRef]

190. Zhao, Y.; Abdullayev, E.; Vasiliev, A.; Lvov, Y. Halloysite Nanotubule Clay for Efficient Water Purification. J. Colloid Interface Sci. 2013, 406, 121-129. [CrossRef] [PubMed]

191. Jinhua, W.; Xiang, Z.; Bing, Z.; Yafei, Z.; Rui, Z.; Jindun, L.; Rongfeng, C. Rapid Adsorption of Cr (VI) on Modified Halloysite Nanotubes. Desalination 2010, 259, 22-28. [CrossRef] 
192. Al-Beladi, A.A.; Kosa, S.A.; Wahab, R.A.; Salam, M.A. Removal of Orange G Dye from Water Using Halloysite NanoclaySupported ZnO Nanoparticles. Desalin. Water Treat. 2020, 196, 287-298. [CrossRef]

193. Kanani-Jazi, M.H.; Akbari, S. Amino-Dendritic and Carboxyl Functionalized Halloysite Nanotubes for Highly Efficient Removal of Cationic and Anionic Dyes: Kinetic, Isotherm, and Thermodynamic Studies. J. Environ. Chem. Eng. 2021, 9, 105214. [CrossRef]

194. Brigatti, M.F.; Galan, E.; Theng, B.K.G. Structures and Mineralogy of Clay Minerals. Dev. Clay Sci. 2006, 1, $19-86$.

195. Sprynskyy, M.; Sokol, H.; Rafińska, K.; Brzozowska, W.; Railean-Plugaru, V.; Pomastowski, P.; Buszewski, B. Preparation of AgNPs/Saponite Nanocomposites without Reduction Agents and Study of Its Antibacterial Activity. Colloids Surf. B Biointerfaces 2019, 180, 457-465. [CrossRef]

196. Lima, L.C.B.; Silva, F.C.; Silva-Filho, E.C.; Fonseca, M.G.; Zhuang, G.; Jaber, M. Saponite-Anthocyanin Derivatives: The Role of Organoclays in Pigment Photostability. Appl. Clay Sci. 2020, 191, 105604. [CrossRef]

197. Brandão Lima, L.C.; Castro-Silva, F.; Silva-Filho, E.C.; Fonseca, M.G.; Jaber, M. Saponite-Anthocyanin Pigments: Slipping between the Sheets. Microporous Mesoporous Mater. 2020, 300, 110148. [CrossRef]

198. Fatimah, I.; Nurillahi, R.; Sahroni, I.; Muraza, O. TiO 2 -Pillared Saponite and Photosensitization Using a Ruthenium Complex for Photocatalytic Enhancement of the Photodegradation of Bromophenol Blue. Appl. Clay Sci. 2019, 183, 105302. [CrossRef]

199. Kenne Dedzo, G.; Rigolet, S.; Josien, L.; Ngameni, E.; Dzene, L. Functionalization of Synthetic Saponite: Identification of Grafting Sites and Application for Anions Sequestration. Appl. Surf. Sci. 2021, 567, 150911. [CrossRef]

200. Fernández-González, M.V.; Carretero, M.I.; Martín-García, J.M.; Molinero-García, A.; Delgado, R. Peloids Prepared with Three Mineral-Medicinal Waters from Spas in Granada. Their Suitability for Use in Pelotherapy. Appl. Clay Sci. 2021, 202, 105969. [CrossRef]

201. Casagrande, M.; Storaro, L.; Lenarda, M.; Rossini, S. Solid Acid Catalysts from Clays: Oligomerization of 1-Pentene on Al-Pillared Smectites. Catal. Commun. 2005, 6, 568-572. [CrossRef]

202. Takagi, S.; Shimada, T.; Ishida, Y.; Fujimura, T.; Masui, D.; Tachibana, H.; Eguchi, M.; Inoue, H. Size-Matching Effect on Inorganic Nanosheets: Control of Distance, Alignment, and Orientation of Molecular Adsorption as a Bottom-up Methodology for Nanomaterials. Langmuir 2013, 29, 2108-2119. [CrossRef] [PubMed]

203. Carrado, K.A.; Decarreau, A.; Petit, S.; Bergaya, F.; Lagaly, G. Synthetic Clay Minerals and Purification of Natural Clays. Dev. Clay Sci. 2006, 1, 115-139.

204. Utracki, L.A.; Sepehr, M.; Boccaleri, E. Synthetic, Layered Nanoparticles for Polymeric Nanocomposites (PNCs). Polym. Adv. Technol. 2007, 18, 1-37. [CrossRef]

205. Franco, F.; Benítez-Guerrero, M.; Gonzalez-Triviño, I.; Pérez-Recuerda, R.; Assiego, C.; Cifuentes-Melchor, J.; Pascual-Cosp, J. Low-Cost Aluminum and Iron Oxides Supported on Dioctahedral and Trioctahedral Smectites: A Comparative Study of the Effectiveness on the Heavy Metal Adsorption from Water. Appl. Clay Sci. 2016, 119, 321-332. [CrossRef]

206. Suquet, H.; Iiyama, J.T.; Kodama, H.; Pezerat, H. Synthesis and Swelling Properties of Saponites with Increasing Layer Charge. Clays Clay Miner. 1977, 25, 231-242. [CrossRef]

207. Kloprogge, J.T.; Komarneni, S.; Amonette, J.E. Synthesis of Smectite Clay Minerals: A Critical Review. Clays Clay Miner. 1999, 47, 529-554. [CrossRef]

208. Zhang, D.; Zhou, C.-H.; Lin, C.-X.; Tong, D.-S.; Yu, W.-H. Synthesis of Clay Minerals. Appl. Clay Sci. 2010, 50, 1-11. [CrossRef]

209. Jaber, M.; Komarneni, S.; Zhou, C.-H. Synthesis of Clay Minerals. In Developments in Clay Science; Elsevier: Amsterdam, The Netherlands, 2013; Volume 5, pp. 223-241.

210. Carniato, F.; Bisio, C.; Psaro, R.; Marchese, L.; Guidotti, M. Niobium (V) Saponite Clay for the Catalytic Oxidative Abatement of Chemical Warfare Agents. Angew. Chem. Int. Ed. 2014, 53, 10095-10098. [CrossRef] [PubMed]

211. Baldermann, A.; Dohrmann, R.; Kaufhold, S.; Nickel, C.; Letofsky-Papst, I.; Dietzel, M. The Fe-Mg-Saponite Solid Solution Series-A Hydrothermal Synthesis Study. Clay Miner. 2014, 49, 391-415. [CrossRef]

212. Zhang, C.; He, H.; Tao, Q.; Ji, S.; Li, S.; Ma, L.; Su, X.; Zhu, J. Metal Occupancy and Its Influence on Thermal Stability of Synthetic Saponites. Appl. Clay Sci. 2017, 135, 282-288. [CrossRef]

213. Trujillano, R.; Rico, E.; Vicente, M.A.; Herrero, M.; Rives, V. Microwave Radiation and Mechanical Grinding as New Ways for Preparation of Saponite-like Materials. Appl. Clay Sci. 2010, 48, 32-38. [CrossRef]

214. Gebretsadik, F.B.; Salagre, P.; Cesteros, Y. Use of Polymer as Template in Microwave Synthesis of Saponite. Study of Several Factors of Influence. Appl. Clay Sci. 2014, 87, 170-178. [CrossRef]

215. Suquet, H.; Malard, C.; Copin, E.; Pezerat, H. Variation Du Paramètre b et de La Distance Basale $\mathrm{d}_{001}$ Dans Une Série de Saponites à Charge Croissante: I. Etats Hydratés. Clay Miner. 1981, 16, 53-67. [CrossRef]

216. Ferrage, E.; Lanson, B.; Michot, L.J.; Robert, J.-L. Hydration Properties and Interlayer Organization of Water and Ions in Synthetic Na-Smectite with Tetrahedral Layer Charge. Part 1. Results from X-Ray Diffraction Profile Modeling. J. Phys. Chem. C 2010, 114, 4515-4526. [CrossRef]

217. Dazas, B.; Lanson, B.; Delville, A.; Robert, J.-L.; Komarneni, S.; Michot, L.J.; Ferrage, E. Influence of Tetrahedral Layer Charge on the Organization of Interlayer Water and Ions in Synthetic Na-Saturated Smectites. J. Phys. Chem. C 2015, 119, 4158-4172. [CrossRef]

218. Ferrage, E. Investigation of the Interlayer Organization of Water and Ions in Smectite from the Combined Use of Diffraction Experiments and Molecular Simulations. A Review of Methodology, Applications, and Perspectives. Clays Clay Miner. 2016, 64, 348-373. [CrossRef] 
219. Eguchi, M.; Momotake, M.; Inoue, F.; Oshima, T.; Maeda, K.; Higuchi, M. Inert Layered Silicate Improves the Electrochemical Responses of a Metal Complex Polymer. ACS Appl. Mater. Interfaces 2017, 9, 35498-35503. [CrossRef] [PubMed]

220. Kurokawa, H.; Hayasaka, M.; Yamamoto, K.; Sakuragi, T.; Ohshima, M.; Miura, H. Self-Assembled Heterogeneous Late TransitionMetal Catalysts for Ethylene Polymerization; New Approach to Simple Preparation of Iron and Nickel Complexes Immobilized in Clay Mineral Interlayer. Catal. Commun. 2014, 47, 13-17. [CrossRef]

221. Sas, S.; Danko, M.; Bizovská, V.; Lang, K.; Bujdák, J. Highly Luminescent Hybrid Materials Based on Smectites with Polyethylene Glycol Modified with Rhodamine Fluorophore. Appl. Clay Sci. 2017, 138, 25-33. [CrossRef]

222. Marcal, L.; de Faria, E.H.; Nassar, E.J.; Trujillano, R.; Martin, N.; Vicente, M.A.; Rives, V.; Gil, A.; Korili, S.A.; Ciuffi, K.J. Organically Modified Saponites: SAXS Study of Swelling and Application in Caffeine Removal. ACS Appl. Mater. Interfaces 2015, 7, 10853-10862. [CrossRef] [PubMed]

223. Sato, K.; Fujimoto, K.; Dai, W.; Hunger, M. Quantitative Elucidation of Cs Adsorption Sites in Clays: Toward Sophisticated Decontamination of Radioactive Cs. J. Phys. Chem. C 2016, 120, 1270-1274. [CrossRef]

224. Herney-Ramirez, J.; Silva, A.M.T.; Vicente, M.A.; Costa, C.A.; Madeira, L.M. Degradation of Acid Orange 7 Using a SaponiteBased Catalyst in Wet Hydrogen Peroxide Oxidation: Kinetic Study with the Fermi's Equation. Appl. Catal. B Environ. 2011, 101, 197-205. [CrossRef]

225. Huggett, J.M. Clay Minerals, 2nd ed.; Alderton, D., Ed.; Academic Press: Oxford, UK, 2021; pp. 341-349, ISBN 978-0-08-102909-1.

226. Grim, R.E. Clay Mineralogy, 1st ed.; McGraw-Hill: New York, NY, USA, 1953.

227. Ragu, S.; Dardillac, E.; Brooks, D.A.; Castro-Smirnov, F.A.; Aranda, P.; Ruiz-Hitzky, E.; Lopez, B.S. Responses of Human Cells to Sepiolite Interaction. Appl. Clay Sci. 2020, 194, 105655. [CrossRef]

228. Wang, F.; Ding, Y.; Hao, M.; Fang, B.; Liang, J. Applied Clay Science Novel Fabrication of a Sepiolite Supported Cobalt-Based Catalyst via a Coprecipitation-Reduction Method. Appl. Clay Sci. 2020, 105909. [CrossRef]

229. Chen, H.; Zhang, Z.; Zhuang, G.; Jiang, R. A New Method to Prepare 'Maya Red' Pigment from Sepiolite and Basic Red 46. Appl. Clay Sci. 2019, 174, 38-46. [CrossRef]

230. Galán, E. Properties and Applications of Palygorskite-Sepiolite Clays. Clay Miner. 1996, 31, 443-453. [CrossRef]

231. Hamid, Y.; Tang, L.; Hussain, B.; Usman, M.; Liu, L.; Ulhassan, Z.; He, Z.; Yang, X. Sepiolite Clay: A Review of Its Applications to Immobilize Toxic Metals in Contaminated Soils and Its Implications in Soil-Plant System. Environ. Technol. Innov. 2021, 23, 101598. [CrossRef]

232. Han, Z.-X.; Zhu, Z.; Wu, D.-D.; Wu, J.; Liu, Y.-R. Adsorption Kinetics and Thermodynamics of Acid Blue 25 and Methylene Blue Dye Solutions on Natural Sepiolite. Synth. React. Inorg. Met.-Org. Nano-Met. Chem. 2014, 44, 140-147. [CrossRef]

233. Rytwo, G.; Nir, S.; Margulies, L.; Casal, B.; Merino, J.; Ruiz-Hitzky, E.; Serratosa, J.M. Adsorption of Monovalent Organic Cations on Sepiolite: Experimental Results and Model Calculations. Clays Clay Miner. 1998, 46, 340-348. [CrossRef]

234. Doke, K.M.; Khan, E.M. Equilibrium, Kinetic and Diffusion Mechanism of Cr (VI) Adsorption onto Activated Carbon Derived from Wood Apple Shell. Arab. J. Chem. 2017, 10, S252-S260. [CrossRef]

235. Santos, S.C.R.; Boaventura, R.A.R. Adsorption Modelling of Textile Dyes by Sepiolite. Appl. Clay Sci. 2008, 42, 137-145. [CrossRef]

236. Hamid, Y.; Tang, L.; Hussain, B.; Usman, M.; Rehman Hashmi, M.L.U.; Bilal Khan, M.; Yang, X.; He, Z. Immobilization and Sorption of $\mathrm{Cd}$ and $\mathrm{Pb}$ in Contaminated Stagnic Anthrosols as Amended with Biochar and Manure Combined with Inorganic Additives. J. Environ. Manag. 2020, 257, 109999. [CrossRef]

237. Bilgiç, C. Investigation of the Factors Affecting Organic Cation Adsorption on Some Silicate Minerals. J. Colloid Interface Sci. 2005, 281, 33-38. [CrossRef] [PubMed]

238. Tümsek, F.; Avc1, O. Investigation of Kinetics and Isotherm Models for the Acid Orange 95 Adsorption from Aqueous Solution onto Natural Minerals. J. Chem. Eng. Data 2013, 58, 551-559. [CrossRef]

239. He, Z.; Ren, B.; Hursthouse, A.; Wang, Z. Efficient Removal of Cd (II) Using $\mathrm{SiO}_{2}-\mathrm{Mg}(\mathrm{OH})_{2}$ Nanocomposites Derived from Sepiolite. Int. J. Environ. Res. Public Health 2020, 17, 2223. [CrossRef]

240. Santos, S.C.R.; Boaventura, R.A.R. Adsorption of Cationic and Anionic Azo Dyes on Sepiolite Clay: Equilibrium and Kinetic Studies in Batch Mode. J. Environ. Chem. Eng. 2016, 4, 1473-1483. [CrossRef]

241. Cheng, H.; Zhu, Q.; Xing, Z. Adsorption of Ammonia Nitrogen in Low Temperature Domestic Wastewater by Modification Bentonite. J. Clean. Prod. 2019, 233, 720-730. [CrossRef]

242. El Miz, M.; Akichoh, H.; Berraaouan, D.; Salhi, S.; Tahani, A. Chemical and Physical Characterization of Moroccan Bentonite Taken from Nador (North of Morocco). Am. J. Chem. 2017, 7, 105-112.

243. Angar, Y.; Djelali, N.-E.; Kebbouche-Gana, S. Investigation of Ammonium Adsorption on Algerian Natural Bentonite. Environ. Sci. Pollut. Res. 2017, 24, 11078-11089. [CrossRef] [PubMed]

244. Kaufhold, S.; Dohrmann, R.; Weber, C. Evolution of the PH Value at the Vicinity of the Iron-Bentonite Interface. Appl. Clay Sci. 2020, 201, 105929. [CrossRef]

245. Drobíková, K.; Štrbová, K.; Tokarčíková, M.; Motyka, O.; Seidlerová, J. Magnetically Modified Bentonite: Characterization and Stability. Mater. Today Proc. 2021, 37, 53-57. [CrossRef]

246. Sakr, M.A.; Mohamed, M.G.A.; Wu, R.; Shin, S.R.; Kim, D.; Kim, K.; Siddiqua, S. Development of Bentonite-Gelatin Nanocomposite Hybrid Hydrogels for Tissue Engineering. Appl. Clay Sci. 2020, 199, 105860. [CrossRef]

247. El-nagar, D.A.; Hereimas, D. Soil \& Tillage Research Synthesis and Characterization of Nano Bentonite and Its Effect on Some Properties of Sandy Soils. Soil Tillage Res. 2021, 208, 104872. [CrossRef] 
248. Peng, L.; Chen, B.; Zhao, Y. Quantitative Characterization and Comparsion of Bentonite Microstructure by Small Angle X-Ray Scattering and Nitrogen Adsorption. Constr. Build. Mater. 2020, 262, 120863. [CrossRef]

249. Tohdee, K.; Kaewsichan, L. Enhancement of Adsorption Efficiency of Heavy Metal Cu (II) and Zn (II) onto Cationic Surfactant Modified Bentonite. J. Environ. Chem. Eng. 2018, 6, 2821-2828. [CrossRef]

250. Jiménez-Castañeda, M.E.; Medina, D.I. Use of Surfactant-Modified Zeolites and Clays for the Removal of Heavy Metals from Water. Water 2017, 9, 235. [CrossRef]

251. Munir, M.; Nazar, M.F.; Zafar, M.N. Removal of Amaranth Dye over Surfactant Modified Dull Pink Clay from Aqueous Medium. Int. J. Environ. Anal. Chem. 2021, 101, 2848-2865. [CrossRef]

252. Nadeem, M.; Mahmood, A.; Shahid, S.A.; Shah, S.S.; Khalid, A.M.; McKay, G. Sorption of Lead from Aqueous Solution by Chemically Modified Carbon Adsorbents. J. Hazard. Mater. 2006, 138, 604-613. [CrossRef] [PubMed]

253. Khobragade, M.U.; Pal, A. Adsorptive Removal of Mn (II) from Water and Wastewater by Surfactant-Modified Alumina. Desalin. Water Treat. 2016, 57, 2775-2786. [CrossRef]

254. Fiol, N.; Villaescusa, I.; Martínez, M.; Miralles, N.; Poch, J.; Serarols, J. Sorption of Pb (II), Ni (II), Cu (II) and Cd (II) from Aqueous Solution by Olive Stone Waste. Sep. Purif. Technol. 2006, 50, 132-140. [CrossRef]

255. AjayKumar, A.V.; Darwish, N.A.; Hilal, N. Study of Various Parameters in the Biosorption of Heavy Metals on Activated Sludge. World Appl. Sci. J. 2009, 5, 32-40.

256. Abbasi, S.; Foroutan, R.; Esmaeili, H.; Esmaeilzadeh, F. Preparation of Activated Carbon from Worn Tires for Removal of Cu (II), $\mathrm{Ni}$ (II) and Co (II) Ions from Synthetic Wastewater. Desalin. Water Treat 2019, 141, 269-278. [CrossRef]

257. Cai, C.; Wu, X.; Liu, W.; Zhu, W.; Chen, H.; Qiu, J.C.D.; Sun, C.-N.; Liu, J.; Wei, Q.; Shi, Y. Selective Laser Melting of Near- $\alpha$ Titanium Alloy Ti-6Al-2Zr-1Mo-1V: Parameter Optimization, Heat Treatment and Mechanical Performance. J. Mater. Sci. Technol. 2020, 57, 51-64. [CrossRef]

258. Chen, J.; Cai, Y.; Clark, M.; Yu, Y. Equilibrium and Kinetic Studies of Phosphate Removal from Solution onto a Hydrothermally Modified Oyster Shell Material. PLoS ONE 2013, 8, e60243. [CrossRef] [PubMed]

259. Tamjidi, S.; Esmaeili, H. Chemically Modified $\mathrm{CaO} / \mathrm{Fe}_{3} \mathrm{O}_{4}$ Nanocomposite by Sodium Dodecyl Sulfate for $\mathrm{Cr}$ (III) Removal from Water. Chem. Eng. Technol. 2019, 42, 607-616. [CrossRef]

260. Mudzielwana, R.; Gitari, M.W.; Ndungu, P. Performance Evaluation of Surfactant Modified Kaolin Clay in As (III) and As (V) Adsorption from Groundwater: Adsorption Kinetics, Isotherms and Thermodynamics. Heliyon 2019, 5, e02756. [CrossRef]

261. Xi, H.; Li, Q.; Yang, Y.; Zhang, J.; Guo, F.; Wang, X.; Xu, S.; Ruan, S. Highly Effective Removal of Phosphate from Complex Water Environment with Porous Zr-Bentonite Alginate Hydrogel Beads: Facile Synthesis and Adsorption Behavior Study. Appl. Clay Sci. 2021, 201, 105919. [CrossRef]

262. de Queiroga, L.N.F.; França, D.B.; Rodrigues, F.; Santos, I.M.G.; Fonseca, M.G.; Jaber, M. Functionalized Bentonites for Dye Adsorption: Depollution and Production of New Pigments. J. Environ. Chem. Eng. 2019, 7, 103333. [CrossRef]

263. Herrera, N.N.; Letoffe, J.-M.; Putaux, J.-L.; David, L.; Bourgeat-Lami, E. Aqueous Dispersions of Silane-Functionalized Laponite Clay Platelets. A First Step toward the Elaboration of Water-Based Polymer/Clay Nanocomposites. Langmuir 2004, 20, $1564-1571$.

264. Ghadiri, M.; Hau, H.; Chrzanowski, W.; Agus, H.; Rohanizadeh, R. Laponite Clay as a Carrier for in Situ Delivery of Tetracycline. RSC Adv. 2013, 3, 20193-20201. [CrossRef]

265. Pálková, H.; Madejová, J.; Zimowska, M.; Bielańska, E.; Olejniczak, Z.; Lityńska-Dobrzyńska, L.; Serwicka, E.M. Laponite-Derived Porous Clay Heterostructures: I. Synthesis and Physicochemical Characterization. Microporous Mesoporous Mater. 2010, 127, $228-236$. [CrossRef]

266. Bienia, M.; Danglade, C.; Lecomte, A.; Brevier, J.; Pagnoux, C. Cylindrical Couette Flow of Laponite Dispersions. Appl. Clay Sci. 2018, 162, 83-89. [CrossRef]

267. Loginov, M.; Lebovka, N.; Vorobiev, E. Laponite Assisted Dispersion of Carbon Nanotubes in Water. J. Colloid Interface Sci. 2012, 365, 127-136. [CrossRef]

268. Manilo, M.V.; Lebovka, N.; Barany, S. Combined Effect of Cetyltrimethylammonium Bromide and Laponite Platelets on Colloidal Stability of Carbon Nanotubes in Aqueous Suspensions. J. Mol. Liq. 2017, 235, 104-110. [CrossRef]

269. Silva, J.M.; Barud, H.S.; Meneguin, A.B.; Constantino, V.R.L.; Ribeiro, S.J.L. Inorganic-Organic Bio-Nanocomposite Films Based on Laponite and Cellulose Nanofibers (CNF). Appl. Clay Sci. 2019, 168, 428-435. [CrossRef]

270. Le Coeur, C.; Lorthioir, C.; Feoktystov, A.; Wu, B.; Volet, G.; Amiel, C. Laponite/Poly(2-Methyl-2-Oxazoline) Hydrogels: Interplay between Local Structure and Rheological Behaviour. J. Colloid Interface Sci. 2021, 582, 149-158. [CrossRef]

271. Yu, D.; Li, G.; Kong, F.; Wang, H.; Liu, W.; Song, Z.; Meng, X.; Zhao, J.R.H. Encapsulation of Alkenylsuccinic Anhydride Oil Droplets in Laponite Nanoparticles Modified by Carbon Nitride Quantum Dots: Enhancement of Emulsion Stability and Paper Sizing Performance. Appl. Clay Sci. 2020, 191, 105608. [CrossRef]

272. Zhang, R.; Xie, L.; Wu, H.; Yang, T.; Zhang, Q.; Tian, Y.; Liu, Y.; Han, X.; Guo, W.; He, M.; et al. Alginate/Laponite Hydrogel Microspheres Co-Encapsulating Dental Pulp Stem Cells and VEGF for Endodontic Regeneration. Acta Biomater. 2020, 113, 305-316. [CrossRef] [PubMed]

273. Elkatatny, S. Improved Carbonation Resistance and Durability of Saudi Class G Oil Well Cement Sheath in $\mathrm{CO}_{2}$ Rich Environments Using Laponite. J. Pet. Sci. Eng. 2021, 196, 107812. [CrossRef]

274. Au, P.-I.; Hassan, S.; Liu, J.; Leong, Y.-K. Behaviour of LAPONITE ${ }^{\circledR}$ Gels: Rheology, Ageing, PH Effect and Phase State in the Presence of Dispersant. Chem. Eng. Res. Des. 2015, 101, 65-73. [CrossRef] 
275. Valencia, G.A.; Djabourov, M.; Carn, F.; Sobral, P.J.A. Novel Insights on Swelling and Dehydration of Laponite. Colloid Interface Sci. Commun. 2018, 23, 1-5. [CrossRef]

276. Jatav, S.; Joshi, Y.M. Chemical Stability of Laponite in Aqueous Media. Appl. Clay Sci. 2014, 97, 72-77. [CrossRef]

277. Zhang, P.; Wang, J.; Jia, Y.; Li, W.; Tan, X.; Zhang, D.; Xu, S.; Zhang, P.; Wei, C.; Miao, S. Encapsulating Spinel Nancrystals in Laponite Cages and Applications in Molecular Oxidation of Cyclohexane. Appl. Clay Sci. 2019, 181, 105226. [CrossRef]

278. Takeno, H.; Sato, C. Effects of Molecular Mass of Polymer and Composition on the Compressive Properties of Hydrogels Composed of Laponite and Sodium Polyacrylate. Appl. Clay Sci. 2016, 123, 141-147. [CrossRef]

279. Zeng, H.; Yu, Z.; Peng, Y.; Zhu, L. Environmentally Friendly Electrostatically Driven Self-Assembled LDH/GO/PVDF Composite Membrane for Water Treatment. Appl. Clay Sci. 2019, 183, 105322. [CrossRef]

280. Muller, F.; Salonen, A.; Glatter, O. Monoglyceride-Based Cubosomes Stabilized by Laponite: Separating the Effects of Stabilizer, PH and Temperature. Colloids Surf. A Physicochem. Eng. Asp. 2010, 358, 50-56. [CrossRef]

281. van den Dungen, E.T.A.; Hartmann, P.C. Synergistic Effect of Laponite RD and Oil Soluble Surfactant in Stabilization of Miniemulsions. Appl. Clay Sci. 2012, 55, 120-124. [CrossRef]

282. Taguchi, T.; Kohno, Y.; Shibata, M.; Tomita, Y.; Fukuhara, C.; Maeda, Y. An Easy and Effective Method for the Intercalation of Hydrophobic Natural Dye into Organo-Montmorillonite for Improved Photostability. J. Phys. Chem. Solids 2018, 116, 168-173. [CrossRef]

283. Ribeiro, H.L.; de Oliveira, A.V.; de Brito, E.S.; Ribeiro, P.R.V.; Azeredo, H.M.C. Stabilizing Effect of Montmorillonite on Acerola Juice Anthocyanins. Food Chem. 2018, 245, 966-973. [CrossRef]

284. Kohno, Y.; Senga, M.; Shibata, M.; Yoda, K.; Matsushima, R.; Tomita, Y.; Maeda, Y.; Kobayashi, K. Stabilization of Flavylium Dye by Incorporation into Fe-Containing Mesoporous Silicate. Microporous Mesoporous Mater. 2011, 141, 77-80. [CrossRef]

285. Kohno, Y.; Asai, S.; Shibata, M.; Fukuhara, C.; Maeda, Y.; Tomita, Y.; Kobayashi, K. Improved Photostability of Hydrophobic Natural Dye Incorporated in Organo-Modified Hydrotalcite. J. Phys. Chem. Solids 2014, 75, 945-950. [CrossRef]

286. Boyaci, T.; Orakdogen, N. Poly(N,N-Dimethylaminoethyl Methacrylate-Co-2-Acrylamido-2-Methyl-Propanosulfonic Acid)/Laponite Nanocomposite Hydrogels and Cryogels with Improved Mechanical Strength and Rapid Dynamic Properties. Appl. Clay Sci. 2016, 121-122, 162-173. [CrossRef]

287. Wang, Z.; Li, J.; Sun, Y.; Peng, J.; Wang, J.; Hao, Y.; Li, W.; Zhang, P.; Ning, W.; Miao, S. Laponite Elementary Sheets Assisted Fluorescence Resonance Energy Transfer: A Demonstration by Langmuir-Blodgett Technique. Dye. Pigment. 2021, 196, 109800. [CrossRef]

288. Prasannan, A.; Udomsin, J.; Tsai, H.-C.; Wang, C.-F.; Lai, J.-Y. Robust Underwater Superoleophobic Membranes with Bio-Inspired Carrageenan/Laponite Multilayers for the Effective Removal of Emulsions, Metal Ions, and Organic Dyes from Wastewater. Chem. Eng. J. 2020, 391, 123585. [CrossRef]

289. Akil, J.; Ciotonea, C.; Siffert, S.; Royer, S.; Pirault-Roy, L.; Cousin, R.; Poupin, C. NO Reduction by CO under Oxidative Conditions over CoCuAl Mixed Oxides Derived from Hydrotalcite-like Compounds: Effect of Water. Catal. Today 2021. [CrossRef]

290. Carlino, S. Chemistry between the Sheets. Chem. Br. 1997, 33, 59-62.

291. Ulibarri, M.A.; Pavlovic, I.; Barriga, C.; Hermosın, M.C.; Cornejo, J. Adsorption of Anionic Species on Hydrotalcite-like Compounds: Effect of Interlayer Anion and Crystallinity. Appl. Clay Sci. 2001, 18, 17-27. [CrossRef]

292. Bish, D.L. Anion-Exchange in Takovite: Applications to Other Hydroxide Minerals. Bull. Mineral. 1980, 103, 170-175. [CrossRef]

293. Miyata, S. Physico-Chemical Properties of Synthetic Hydrotalcites in Relation to Composition. Clays Clay Miner. 1980, 28, 50-56. [CrossRef]

294. Zhu, M.-X.; Li, Y.-P.; Xie, M.; Xin, H.-Z. Sorption of an Anionic Dye by Uncalcined and Calcined Layered Double Hydroxides: A Case Study. J. Hazard. Mater. 2005, 120, 163-171. [CrossRef]

295. Lakraimi, M.; Legrouri, A.; Barroug, A.; Besse, J.-P. Removal of Pesticides from Water by Anionic Clays. J. Chim. Phys. Physico-Chim. Biol. 1999, 96, 470-478. [CrossRef]

296. Sato, T.; Kato, K.; Endo, T.; Shimada, M. Preparation and Chemical Properties of Magnesium Aluminium Oxide Solid Solutions. React. Solids 1986, 2, 253-260. [CrossRef]

297. Salomao, R.; Milena, L.M.; Wakamatsu, M.H.; Pandolfelli, V.C. Hydrotalcite Synthesis via Co-Precipitation Reactions Using MgO and $\mathrm{Al}(\mathrm{OH})_{3}$ Precursors. Ceram. Int. 2011, 37, 3063-3070. [CrossRef]

298. Bouraada, M.; Lafjah, M.; Ouali, M.S.; de Menorval, L.C. Basic Dye Removal from Aqueous Solutions by Dodecylsulfate-and Dodecyl Benzene Sulfonate-Intercalated Hydrotalcite. J. Hazard. Mater. 2008, 153, 911-918. [CrossRef]

299. Cavani, F.; Trifiro, F.; Vaccari, A. Hydrotalcite-Type Anionic Clays: Preparation, Properties and Applications. Catal. Today 1991, 11, 173-301. [CrossRef]

300. Gasser, M.S.; Mekhamer, H.S.; Abdel Rahman, R.O. Optimization of the Utilization of Mg/Fe Hydrotalcite like Compounds in the Removal of Sr(II) from Aqueous Solution. J. Environ. Chem. Eng. 2016, 4, 4619-4630. [CrossRef]

301. Ogawa, M.; Takee, R.; Okabe, Y.; Seki, Y. Bio-Geo Hybrid Pigment; Clay-Anthocyanin Complex Which Changes Color Depending on the Atmosphere. Dye. Pigment. 2017, 139, 561-565. [CrossRef]

302. Guillermin, D.; Debroise, T.; Trigueiro, P.; de Viguerie, L.; Rigaud, B.; Morlet-Savary, F.; Balme, S.; Janot, J.-M.; Tielens, F.; Michot, L.; et al. New Pigments Based on Carminic Acid and Smectites: A Molecular Investigation. Dye. Pigment. 2019, 160, 971-982. [CrossRef]

303. McKay, G.; Ramprasad, G.; Mowli, P. Desorption and Regeneration of Dye Colours from Low-Cost Materials. Water Res. 1987, 21, 375-377. [CrossRef] 
304. Voudrias, E.; Fytianos, K.; Bozani, E. Sorption-Desorption Isotherms of Dyes from Aqueous Solutions and Wastewaters with Different Sorbent Meterials. Global NEST Int. J. 2018, 4, 75-83. [CrossRef]

305. Yuan, J.; Zhou, S.; You, B.; Wu, L. Organic Pigment Particles Coated with Colloidal Nano-Silica Particles via Layer-by-Layer Assembly. Chem. Mater. 2005, 17, 3587-3594. [CrossRef]

306. Cao, L.; Fei, X.; Zhang, T.; Yu, L.; Gu, Y.; Zhang, B. Modification of CI Pigment Red 21 with Sepiolite and Lithopone in Its Preparation Process. Ind. Eng. Chem. Res. 2014, 53, 31-37. [CrossRef]

307. Dejoie, C.; Martinetto, P.; Dooryhee, E.; Strobel, P.; Blanc, S.; Bordat, P.; Brown, R.; Porcher, F.; Sanchez del Rio, M.; Anne, M. Indigo@ Silicalite: A New Organic-Inorganic Hybrid Pigment. ACS Appl. Mater. Interfaces 2010, 2, 2308-2316. [CrossRef]

308. Raha, S.; Ivanov, I.; Quazi, N.H.; Bhattacharya, S.N. Photo-Stability of Rhodamine-B/Montmorillonite Nanopigments in Polypropylene Matrix. Appl. Clay Sci. 2009, 42, 661-666. [CrossRef]

309. Beltrán, M.I.; Benavente, V.; Marchante, V.; Dema, H.; Marcilla, A. Characterisation of Montmorillonites Simultaneously Modified with an Organic Dye and an Ammonium Salt at Different Dye/Salt Ratios. Properties of These Modified Montmorillonites EVA Nanocomposites. Appl. Clay Sci. 2014, 97, 43-52. [CrossRef]

310. Van der Linden, E.G.; Malta, L.F.B.; Medeiros, M.E. Evaluation of Synthetic Routes to Pigmentary Grade Bismuth Vanadate. Dye. Pigment. 2011, 90, 36-40. [CrossRef]

311. Wang, X.; Mu, B.; Wang, W.; Wang, Q.; Wang, A. A Comparative Study on Color Properties of Different Clay Minerals/BiVO 4 Hybrid Pigments with Excellent Thermal Stability. Appl. Clay Sci. 2019, 181, 105221. [CrossRef]

312. Yi, J.-Z.; Zhang, L.-M. Removal of Methylene Blue Dye from Aqueous Solution by Adsorption onto Sodium Humate/Polyacrylamide/ Clay Hybrid Hydrogels. Bioresour. Technol. 2008, 99, 2182-2186. [CrossRef] [PubMed]

313. Momina; Mohammad, S.; Suzylawati, I. Study of the Adsorption/Desorption of MB Dye Solution Using Bentonite Adsorbent Coating. J. Water Process Eng. 2020, 34, 101155. [CrossRef]

314. Moujahid, E.M.; Lahkale, R.; Ouassif, H.; Bouragba, F.Z.; Elhatimi, W. New Organic Dye/Anionic Clay Hybrid Pigments: Preparation, Optical Properties and Structural Stability. Dye. Pigment. 2019, 162, 998-1004. [CrossRef] 